\title{
Piperaceae do Nordeste brasileiro I: estado do Ceará
}

\begin{tabular}{c}
\hline Elsie Franklin Guimarães ${ }^{1}$ \\
Luiz Carlos da Silva Giordano ${ }^{2}$ \\
\hline
\end{tabular}

\section{RESUMO}

Este trabalho trata das espécies de Piperaceae representadas no estado do Ceará, Brasil, com interesse assentado no conhecimento taxonômico, como também no seu valor medicinal. O tratamento taxonômico compreende descrições, chaves para identificação dos táxons e distribuição geográfica com base no exame de exsicatas de herbários, incluindo tipos. Comentários sobre utilidades e dados ambientais são atribuídos a algumas espécies. Para o Ceará, segundo o material examinado, são assinalados 4 gêneros, separados principalmente pelo hábito e pela disposição das inflorescências, constantes de 35 taxa que se distinguem pelos padrões de nervação foliar, bractéolas florais e frutos. Os indivíduos destes táxons ocorrem nas áreas úmidas das serras de Baturité, Maranguape, Aratanha e Machado; a maioria apresenta distribuição ampla, enquanto que Piper rufipilum Yunck. é espécie endêmica da Chapada do Araripe e Ottonia leptostachia Kunth constituiu-se em uma nova localidade.

Palavras-chaves: Piperaceae/Taxonomia/Flora/Ceará/Medicinais.

\begin{abstract}
The subject of this paper is the Piperaceae species which occur in the state of Ceará, Brazil, with special attention paid to their taxonomy, as well as the medicinal value. The taxonomic treatment used in this study were the following in the examination of dissected dried herbarium specimens including types, descriptions, keys for identification of taxa and geographical distribution. Commentary on the use and ambiental data are presented for some taxa. The State of Ceará denote in the material examined 4 genera, differentiated by habitat and arrangement of inflorescence, in 35 taxa which are distinguishable by their patterns of foliar nervation, floral bracteoles and fruits. The individuals these taxa occur in the humid regions of the mountains of Baturite, Maranguape, Aratanha and Machado; where the majority of them are widely distributed, whereas Piper rufipilum Yunck. is only found in Chapada do Araripe and Ottonia leptostachia Kunth is found in yet another area.
\end{abstract}

Key-words: Piperaceae/Taxonomy/Flora/Ceará/Medicinal.

\section{INTRODUÇÃO}

Estudos taxonômicos vêm sendo desenvolvidos em Piperaceae no Brasil com base nas pesquisas realizadas por T.G. Yuncker, especialista na família, que estabeleceu as diretrizes para o entendimento desse grupo. Em continuidade aos trabalhos encetados para o Brasil, quer sejam no âmbito nacional ou no regional, procurou-se conhecer as espécies da família representadas no nordeste do país, tendo em vista que a literatura informa a importância de algumas como medicinais.
A identificação correta e a divulgação permitirão aos estudiosos e pesquisadores em fitoquímica e aos interessados no desenvolvimento regional a utilização e a conservação destas plantas que, provavelmente, constituirão alternativas para as populações carentes.

O nordeste brasileiro conta com quatro gêneros: Ottonia Spreng., Peperomia Ruiz \& Pav., Piper L. e Pothomorphe Miq., não tendo sido assinalado o gênero Sarchorhachis Trel., exclusivo das Regiões Sudeste e Sul do Brasil.

\footnotetext{
${ }^{1}$ Bolsista do CNPq. / Pesquisadora - Instituto de Pesquisas Jardim Botânico do Rio de Janeiro - Programa Mata Atlântica. Rua Pacheco Leão 915, Jardim Botânico, Rio de Janeiro / RJ - Brasil. CEP 22460-030. eguimar@ jbrj.gov.br

${ }^{2}$ Pesquisador - Instituto de Pesquisas Jardim Botânico do Rio de Janeiro - Programa Diversidade Taxonômica. luiz.giordano@jbrj.gov.br
} 
Como primeira informação, foram estudadas aquelas ocorrentes no estado do Ceará, compreendendo, conforme material examinado, 35 taxa que são tratados neste trabalho, incluindo informações de habitat, distribuição geográfica, dentre outras, como nomes populares e comentários sobre suas utilidades, principalmente daquelas com propriedade medicinal.

No Ceará as espécies encontram-se representadas, principalmente, nas superfícies dos relevos residuais cristalinos mais proeminentes, cujas altitudes e a pequena distância do litoral determinam maiores índices pluviométricos, desenvolvendo solos mais profundos e, conseqüentemente, abrigando uma flora diferenciada. Estas regiões, denominadas serras úmidas, como Aratanha, Baturité e Maranguape, são as preferidas por espécies de Peperomia e certas espécies de Piper, que apresentam indivíduos à sombra.

Nas encostas da Chapada do Araripe, no sul do Ceará, e no topo do planalto do Ibiapaba, na denominada Serra Grande, também foram registradas espécies de Piperaceae.

\section{MATERIAL E MÉTODOS}

$\mathrm{Na}$ Sistemática da família Piperaceae adotou-se a conceituação de Yuncker (1972, 1973, 1974), que considera 5 gêneros para o Brasil: Ottonia Spreng., Piper L., Peperomia Ruiz \& Pav, Pothomorphe Miq. e Sarcorhachis Trel.

Para o estudo taxonômico foi utilizado material dos herbários, nacionais e estrangeiros, B, BM, EAC, F, GH, ILL, K, L, MG, MO, NY, R, RB, SP, U, US, e W (siglas de acordo com Holmgren et al., 1990). Os autores dos táxons estão abreviados conforme Brummitt \& Powell
(1992). Os desenhos realizados em nanquim ilustram detalhes taxonômicos relevantes vegetativos e reprodutivos para melhor identificação dos táxons, os quais foram realizados com o auxílio de microscópio estereoscópio Willd e óptico Carl Zeiss, equipado com câmara clara, em diferentes escalas de aumento. Os dados complementares, como nomes populares, hábito, habitat, utilidades, dentre outros, foram extraídos de literatura, além das informações contidas nas etiquetas das exsicatas consultadas.

\section{RESULTADOS}

Piperaceae C.Agardh, Aphor. bot. 14:201. 1824. Ervas eretas ou escandentes, subarbustos, arbustos ou pequenas árvores, terrestres ou epífitas. Folhas estipuladas, alternas, opostas ou verticiladas, sésseis ou pecioladas, inteiras, de consistência e formas as mais diversas, tricomas muito variados, geralmente dotadas de glândulas translúcidas. Flores aclamídeas, diminutas, monoclinas ou diclinas, protegidas por bracteólas pediceladas ou sésseis, sacadogaleadas ou peltadas, dispostas esparsas ou congestas em espigas, formando umbelas ou não, ou dispostas em racemos, axilares ou terminais, opostos ou não às folhas. Estames 2-6, livres ou adnatos às paredes do ovário; anteras rimosas, bitecas ou unitecas. Ovário súpero, séssil, geralmente imerso na raque, ou pedicelado, unilocular, uniovulado; óvulo basal, ortótropo; estilete presente ou ausente, 1-4 estigmas variáveis na forma. Fruto drupa, séssil ou pedicelado. Endosperma escasso, apresentando perisperma; embrião mínimo.

\section{Gênero tipo: Piper L.}

\section{CHAVE PARA A IDENTIFICAÇÃO DOS GÊNEROS DE PIPERACEAE DO CEARÁ}

1. Inflorescências do tipo racemo

1. Ottonia

1 '. Inflorescências do tipo espiga.

2. Ervas 2. Peperomia

2'. Arbustos ou subarbustos.

3. Espigas solitárias 3. Piper

3'. Espigas não solitárias, dispostas em umbelas 4. Pothomorphe 
1. Ottonia Spreng., Neue Entd. 1: 255. 1820.

Arbustos ou subarbustos nodosos. Folhas com estípulas opositifólias, geralmente curvadas e pequenas, pecioladas, por vezes subsésseis; lâmina elíptica ou ovado-oblonga, glabra ou providas de tricomas. Inflorescências glandulosas ou não, dispostas em racemos opositifólios, solitários, quando jovens apresentam-se como uma pseudo-espiga, quando maduros com pedicelos crescentes; raque pilosa ou não. Flores monoclinas, com bractéolas pediceladas, sacado-galeadas. Estames 4, equidistantes em torno do ovário, livres, com filetes sustentando anteras subglobosas, articuladas. Ovário oblongo, ovado ou elíptico, uniovulado, papiloso; estigmas 4, reflexos. Drupas sulcadas, tetragonais, glabras, agudas ou apiculadas, coroada pelos estigmas persistentes.

Espécie tipo: Ottonia anisum Spreng.

\section{CHAVE PARA A IDENTIFICAÇÃO DAS ESPÉCIES E VARIEDADES DE OTTONIA}

1. Folhas sub-sésseis; flores com pedicelos curtos, menores que os frutos.

2. Folhas e inflorescências não glandulosas 1.1.1. O. leptostachya var. leptostachya

2 '. Folhas e inflorescências glandulosas 1.1.2. O. leptostachya var. glandulosa 1 '. Folhas pecioladas; flores com pedicelos do mesmo comprimento ou maiores que os frutos

1.1.1. Ottonia leptostachya Kunth var. leptostachya, Linnaea 13: 586. 1839.

Arbusto nodoso, com 1-2 m de altura. Folhas sub-sésseis; lâmina elíptica, 12-15 x 5-7 cm, não glandulosa, base com um lado um pouco mais longo que o outro, às vezes cordada, ápice atenuadoacuminado, tricomas hirtos próximos à margem da face abaxial, papirácea ou cartácea. Racemos não glandulosos, ca. $10 \mathrm{~cm}$ compr., 0,5-0,6 cm diâm; bractéolas sacado-galeadas, glabras; flores com os pedicelos curtos, menores que os frutos. Drupa oblonga ou globosa, sulcado-tetragonal, apiculada, em pedicelos com comprimento menor que as mesmas.

Distribuição geográfica: Brasil, nos estados de Paraíba, Bahia, Minas Gerais, Espírito Santo, Rio de Janeiro, São Paulo e Mato Grosso do Sul.

Comentário: Citada pela primeira vez para o estado do Ceará.

Material examinado: Pacatuba, Sitio Monte Alegre, Serra da Aratanha, 4.X.1979, A.J. Castro \& P. Martins s.n. (EAC 7059); São Benedito, Laranjeiras - Inhuçú, embaixo da mata úmida do planalto da Ibiapaba, 14.IV.1990, M.A. Figueiredo s.n. (RB 311061, EAC 18632).

1.1.2. Ottonia leptostachya var. glandulosa Yunck., Bol. Inst. Bot. São Paulo 3: 135. 1966.

Esta variedade diferencia-se da típica pela presença profusa de glândulas nas folhas e inflorescências.

Distribuição geográfica: Brasil, nos estados da Bahia,Espírito Santo, Rio de Janeiroe São Paulo. Comentário: Citada pela primeira vez para o estado do Ceará.

Material examinado: Laranjeiras, Inhuçú, Planalto da Ibiapaba, 14.IV.1990, M.A. Figueiredo s.n. (EAC 18632); Pacatuba, Serra da Aratanha, Sítio Monte Alegre, 04.X.1979, A.J. Castro \& P. Martins s.n. (EAC 7059).

1.2. Ottonia propinqua Kunth, Linnaea 13 : 583. 1839.

Arbusto com 1-2,5 m de altura. Folhas pecioladas; lâmina elíptico-lanceolada, 10-18 x 4-9 cm, glandulosa, base subarredondada, obtusa ou, às vezes, cordada, raro aguda, ápice acuminado, cartácea, glabra em ambas as faces, exceto pelos tricomas híspidos submarginais na base da face abaxial. Racemos glandulosos, 5-6 cm compr., ca.1,3 $\mathrm{cm}$ diâm. quando na frutificação; bractéolas sacado-galeadas, glabras; flores com pedicelos do mesmo comprimento ou maiores que os frutos. Drupa ovada, aguda no ápice, em pedicelo do mesmo comprimento ou maior que a mesma. 
Distribuição geográfica: Brasil, nos estados do Ceará, Paraíba, Pernambuco, Minas Gerais, Espírito Santo, Rio de Janeiro, São Paulo e Santa Catarina.

Comentários:Planta encontrada no alto da Serra de Baturité. Suas inflorescências são consideradas carminativas e estomacais. Conhecida popularmente como chá-bravo, jaguarandi, jaborandi, jaborandi-do-mato, zebrandime, ainda, jambrandim (Peckolt \& Peckolt, 1888; Braga, 1953; Guimarães et al., 1978).

Material examinado: Guaramiranga, Riacho do Capim, 21.VII.1908, Ducke s.n. (MG 1366); id., Sítio Venezuela, 06.I.1989, M.A. Figueiredo et al. s.n. (EAC 15929); s.l., s.d., Fr. Allemão 1463 (R); Sítio Brejo, Mulungu, 13.V.1978, M.A. Figueiredo s.n. (RB 311051, EAC 4394).
2. Peperomia Ruiz \& Pav., Fl. peruv. prodr::8. 1794.

Ervas terrestres ou epífitas, freqüentemente carnosas; caules eretos ou prostrados. Folhas alternas, opostas ou verticiladas; lâmina membranácea, cartácea ou carnosa. Espigas axilares, terminais ou opostas às folhas; bractéolas arredondado-peltadas; flores congestas ou laxas, dispostas em depressão da raque carnosa ou membranácea, às vezes alada, glabra ou com tricomas. Estames 2, laterais. Ovário de globoso a subcilíndrico, glabro; estigma 1. Drupas estipitadas ou não, globosas, ovóides ou subcilíndricas, agudas ou mamiliformes, providas no ápice de um escudo oblíquo ou rostrado, glabras, estigma persistente.

Espécie tipo: Peperomia pellucida (L.) Kunth

\section{CHAVE PARA A IDENTIFICAÇÃO DAS ESPÉCIES E VARIEDADES DE PEPEROMIA}

1. Folhas alternas

2. Lâmina foliar espatulada; drupa provida de escudo rostrado 2.1. P. obtusifolia

2'. Lâmina foliar ovada, ovado-arredondada, ovado-elíptica, ovado-lanceolada, lanceolada ou arredondada; drupa sem escudo rostrado.

3. Lâmina 2-5 mm compr., ápice emarginado; drupa estipitada 2.2. P. emarginella

3'. Lâmina além de $5 \mathrm{~mm}$ compr., ápice não emarginado; drupa não estipitada.

4. Drupa longitudinalmente estriada 2.3. P. pellucida 4'. Drupa não estriada.

5. Lâmina foliar arredondado-peltada na base 2.4. P. lanceolato-peltata

5'. Lâmina foliar não arredondado-peltada na base.

6. Folhas com lâmina negro-pontuada, glabra, se providas de tricomas, apenas uma fileira decorrente na margem do pecíolo.

7. Erva reptante, estolonífera; lâmina foliar ovado-elíptica ... 2.5.1.P. glabella var. glabella

7'. Erva epífita, pendente; lâmina foliar lanceolada ..... 2.5.2. P. glabella var. nervulosa

6'. Folhas com lâmina não negro-pontuada, crespo-pubescente, desprovida de fileira de tricomas decorrentes no pecíolo .....................................2.6. P. rotundifolia

1'. Folhas opostas ou 3-4 verticiladas.

8. Folhas 4-verticiladas; raque da espiga com tricomas

8 '. Folhas opostas ou ternadas; raque da espiga glabra.

9. Lâmina foliar orbicular. 2.7. P. tetraphylla var. tetraphylla

9'. Lâmina foliar não orbicular.

10. Pecíolo viloso, lâmina densamente vilosa quando as folhas são jovens .. 2.9. P. blanda

10 '. Pecíolo glabrescente, lâmina glabra, se pilosa crespo-pubescente apenas na nervura mediana, raramente ao longo das nervuras secundárias.

11. Lâmina foliar 5-8 cm compr., 5-nervada; drupa globosa, ovóide, ápice oblíquo, pseudocúpula ausente 2.10. P. decipiens

11'. Lâmina foliar 2-3 cm compr., 3-nervada; drupa de ovóide a subcilíndrica, ápice agudo, pseudocúpula basal 2.11. P. dahlstedtii 
2.1. Peperomia obtusifolia (L.) A.Dietr., Sp. pl. 1: 154. 1831.

(Fig. 1 d)

Piper obtusifolium L., Sp. pl. 30, 1753.

Erva rupícola, umbrófila; caule suculento, reptante ou ascendente, carnoso, com entrenós relativamente longos providos de longas raízes. Folhas alternas; pecíolo com 2-4 cm compr.; lâmina espatulada, 5,5-8 × 2-4 cm, base subovada ou cuneada, longamente decurrente no pecíolo, ápice obtusamente arredondado, geralmente reto ou mais ou menos emarginado, carnosa, densamente glanduloso-pontuada. Espigas 5-12 cm compr., eretas, solitárias ou aos pares; pedúnculo de 3-4 cm compr., com tricomas hirtos; bractéolas arredondado-peltadas; flores congestas. Drupa ovado-cilíndrica ou cilíndrica, com escudo rostrado no ápice, quase do mesmo comprimento da drupa.

Distribuição geográfica: Continente Americano e Antilhas. No Brasil ocorre nos estados do Amazonas, Pará, Espírito Santo, Rio de Janeiro, São Paulo, Paraná, Santa Catarina e Rio Grande do Sul.

Comentários: As folhas carnosas e espatuladas, as inflorescências longas com flores congestas e os frutos com escudo alongado, dão à espécie condições para uso como ornamental.

Material examinado: Pacatuba, Serra de Aratanha, Sítio Pitaguarí, 10.X.1978, A. Fernandes s.n. (EAC 4186); id., 10.X.1978, A. Fernandes s.n. (EAC 4187); Serra de Maranguape, 23.I.1968,Z. Trinta 1274, E. From Trinta 2207, E. Santos 2215 \& J. Sacco 2411 (R); id., 27.VI.1981, P. Martins \& Nunes s.n. (EAC 10508, RB 306722); s.l., s.d., J. Saldanha 8092 (R); s.l., s.d., Fr. Allemão 1460 (R).

2.2. Peperomia emarginella (Sw. ex Wikstr.) C.DC., Prodr. 16(1): 437. 1869.

Piper emarginellum Sw. ex Wikstr., Kongl. Vetensk. Acad. Handl.:56. 1828.

Erva reptante delicada, glabra ou levemente provida de tricomas; caule filiforme. Folhas alternas; lâmina ovada ou ovado-arredondada, 2-5 x 3-5 mm, base arredondada ou cordada, às vezes levemente peltada, ápice obtuso ou subtruncado-emarginado, glabra, sedoso-ciliada na margem. Espigas terminais, 1-2 mm compr.; pedúnculo ca.1 cm compr.; bractéolas arredondado-peltadas; flores laxamente dispostas. Drupa estipitada, elipsoidal ou obpiriforme, ápice oblíquo-escuteliforme (Yuncker, 1974).

Distribuição geográfica: Brasil, nos estados do Ceará, São Paulo e Paraná.

Material examinado: s.l., s.d., Fr. Allemão \& Cysneiros 1459 (R).

2.3. Peperomia pellucida (L.) Kunth, Nov. gen. sp. 1: 64. 1815.

(Fig. 1 a)

Piper pellucidum L., Sp. pl.: 30. 1753.

Erva terrestre, suculenta, com pontuações translúcidas; caule ereto, ramificado. Folhas alternas, longo-pecioladas; lâmina ovada, 1,52,5 x 1-2 cm, base cordada, ápice agudo, membranácea. Espigas terminais, axilares ou opositifólias, até $5 \mathrm{~cm}$ compr.; pedúnculo ca.5 mm compr.; bractéolas arredondado-peltadas; flores esparsamente dispostas. Drupa elipsóide, não estipitada, longitudinalmente estriada.

Distribuição geográfica: América do Norte, Central (Antilhas) e América do Sul. No Brasil ocorre desde o Amazonas até o Paraná, com representantes em locais úmidos, principalmente em paredões e muito frequiente em jardins.

Comentários: No Brasil, em Santa Catarina, é conhecida como comida-de-jaboti ou ervade-jaboti, erva-de-vidro (Guimarães et al., 1984; Vieira, 1992); é popularmente usada na Amazônia para combater a tosse ou a dor de garganta, sendo ainda antipruriginosa e diurética, utilizada sob a forma de chá ou infusão preparados com as raízes e toda a planta, não raro, é consumida como excelente salada (Van Den Berg, 1993). Outros nomes populares são atribuídos a esta planta, como "corazon de hombre" e "yerba de la plata" em Cuba, "herbe a la curesse" nas Antilhas Francesas (Roig y Mesa, 1988).

Peckolt \& Peckolt (1888), tecem algumas considerações sobre o jaboti-membeca, informando que é uma planta aromática, utilizada 

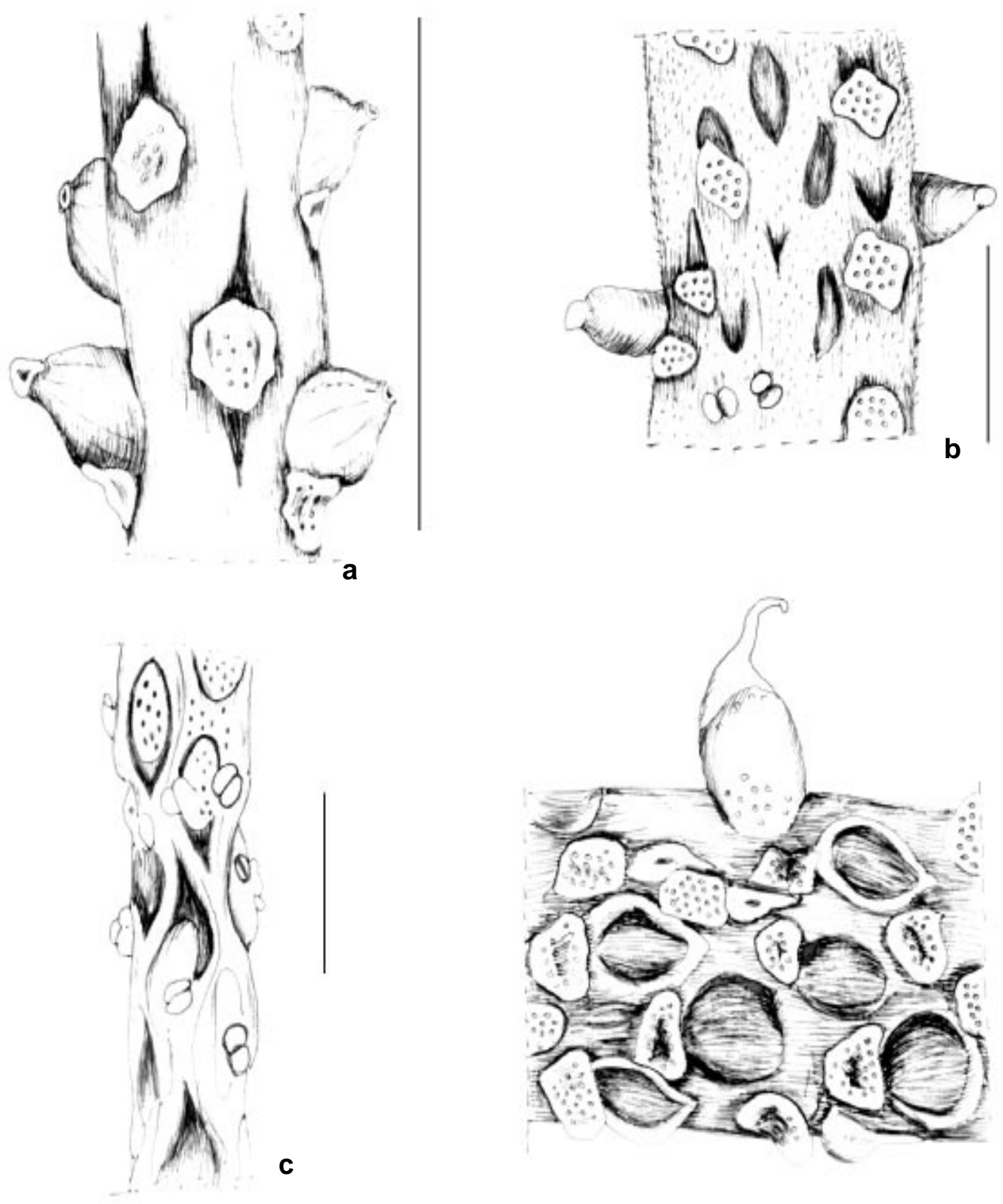

d

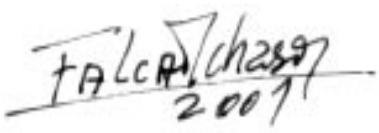

Figura 1 - a) Peperomia pellucida (L.) Humb., Bonpl. et Kunth: parte da espiga detalhando bractéolas e frutos (escala = $1 \mathrm{~mm}$ ); b) Peperomia tetraphylla (G.Forst.) Hook et Arn.: parte da espiga em fruto (escala = $1 \mathrm{~mm}$ ); c) Peperomia glabella (Sw.) A.Dietr.: parte da espiga em flor (escala $=1 \mathrm{~mm}$ ); d) Peperomia obtusifolia (L.) A.Dietr.: parte da espiga em fruto $($ escala $=1 \mathrm{~mm})$. 
sob a forma de infusão em "5 partes das folhas para 100 de água fervida na dose de uma xícara, 3 vezes ao dia", para tratamento de reumatismo. Considerada útil nas inflamações do reto, nas doenças do coração, sendo que o sumo da planta é apreciado quando aplicado sobre mordeduras de cobras (Roíg y Mesa, 1945).

Fosberg \& Sachet (1975), assinalam esta espécie para a Flora da Micronésia, informando seu uso medicinal, em Sonsorol, cujo suco resultante da trituração é aplicado sobre cortes. Silva Teixeira et al. (1991), mencionam a utilização das folhas da erva-dejaboti, sob forma de chá, contra a hipertensão e outras patologias.

Material examinado: Maranguape, 7.V.1909, Ducke s.n. (MG 2264); s.l., s.d., Fr. Allemão 1461 \& Cyneiros (R); s.l., s.d., Saldanha 8093 (R).

2.4. Peperomia lanceolato-peltata C.DC., J. Bot. 4: 136, 1866; Yuncker, Hoehnea 4: 192, fig. 410. 1974.

(Fig. 2 a-c)

Erva com caule espessado, semelhante a rizoma. Folhas alternas; lâmina ovadolanceolada, 4-7 x 2,5-4,5 cm, base arredondadopeltada, ápice acuminado, 7-palmati-nervada, esparsamente vilosa em ambas as faces, ciliadas na margem, membranácea. Espigas axilares ou terminais, $10-15 \mathrm{~cm}$ compr.; pendúnculo com ca. $4 \mathrm{~cm}$ compr.; bractéolas arredondadopeltadas, glabras, sinuosas na margem; flores esparsamente dispostas. Drupa globoso-ovóide, não estipitada, lisa, ápice suboblíquo, verrucoso. Distribuição geográfica: América do Sul. No Brasil encontrada somente no estado do Ceará. Comentários: As folhas longo pecioladas e as lâminas arredondado-peltadas dão a esta espécie características ornamentais. No estado do Ceará somente o exemplar coletado em 1939 documenta esta espécie para o mesmo. Material examinado: Serra de Baturité, 20.VI.1939, Pe. Eugênio Leite 469 (RB).
2.5.1. Peperomia glabella (Sw.) A.Dietr. var. glabella, Sp. pl. 1: 56. 1831.

(Fig.1c)

Piper glabellum Sw., Prodr. 16. 1788.

Erva reptante, estolonífera, com ramos espandidos, glabros, exceto por uma linha de cílios nas margens do pecíolo, ao longo do caule. Folhas alternas, curto-pecioladas; lâmina ovado-elíptica, 2,5-3 x 0,5-2,8 cm, base decorrente no pecíolo, ápice agudo, ciliado, subcarnosa ou membranácea, negro-pontuada em ambas as faces. Espigas longas, eretas, terminais, superando 2-4 ou mais vezes o comprimento da lâmina foliar; pedúnculo 1-1,5 cm compr., glabrescente; raque negropontuada, glabra; bractéolas peltadas; flores esparsamente dispostas. Drupa ovado-globosa, não estipitada, com papilas viscosas, escudo pequeno, levemente oblíquo no ápice.

Distribuição geográfica: Antilhas, Américas Central e do Sul. No Brasil, nos estados do Amapá, Pará, Espírito Santo, Rio de Janeiro, São Paulo e Santa Catarina.

Comentários: Espécie crescendo geralmente no interior da mata, própria de floresta com luz difusa; por suas características morfológicas pode ser cultivada como ornamental. Não foi assinalado nome popular para o Ceará; no Sul do Brasil, em Santa Catarina, é conhecida como erva-de-vidro (Guimarães et al., 1984). Material examinado: Serra de Baturité, IX.1897, Curran 220 (MG); Maranguape, topo da Serra de Maranguape, 28.VI.1981, P. Martins \& E. Nunes s.n. (EAC 10570); Serra de Maranguape, 14.IX.1908, Ducke s.n. (MG 1627); s.1., 1860, Fr. Allemão 1458 (R); s.l., 9.XII.1937, Pe. José Eugênio Leite 465 (RB); s.1., s.d., Saldanha 8091 (R).

2.5.2. Peperomia glabella var. nervulosa (C.DC.) Yunck., Ann. Missouri Bot. Gard. 37: 98, 1950.

Peperomia melanostigma var. nervulosa C.DC., Prodr. 16(1): 409. 1869.

Caracteriza-se principalmente pelo hábito epífito e por apresentar a lâmina foliar lanceolada, 3-8 x 1-3 cm, base aguda e ápice agudo ou longamente acuminado. 


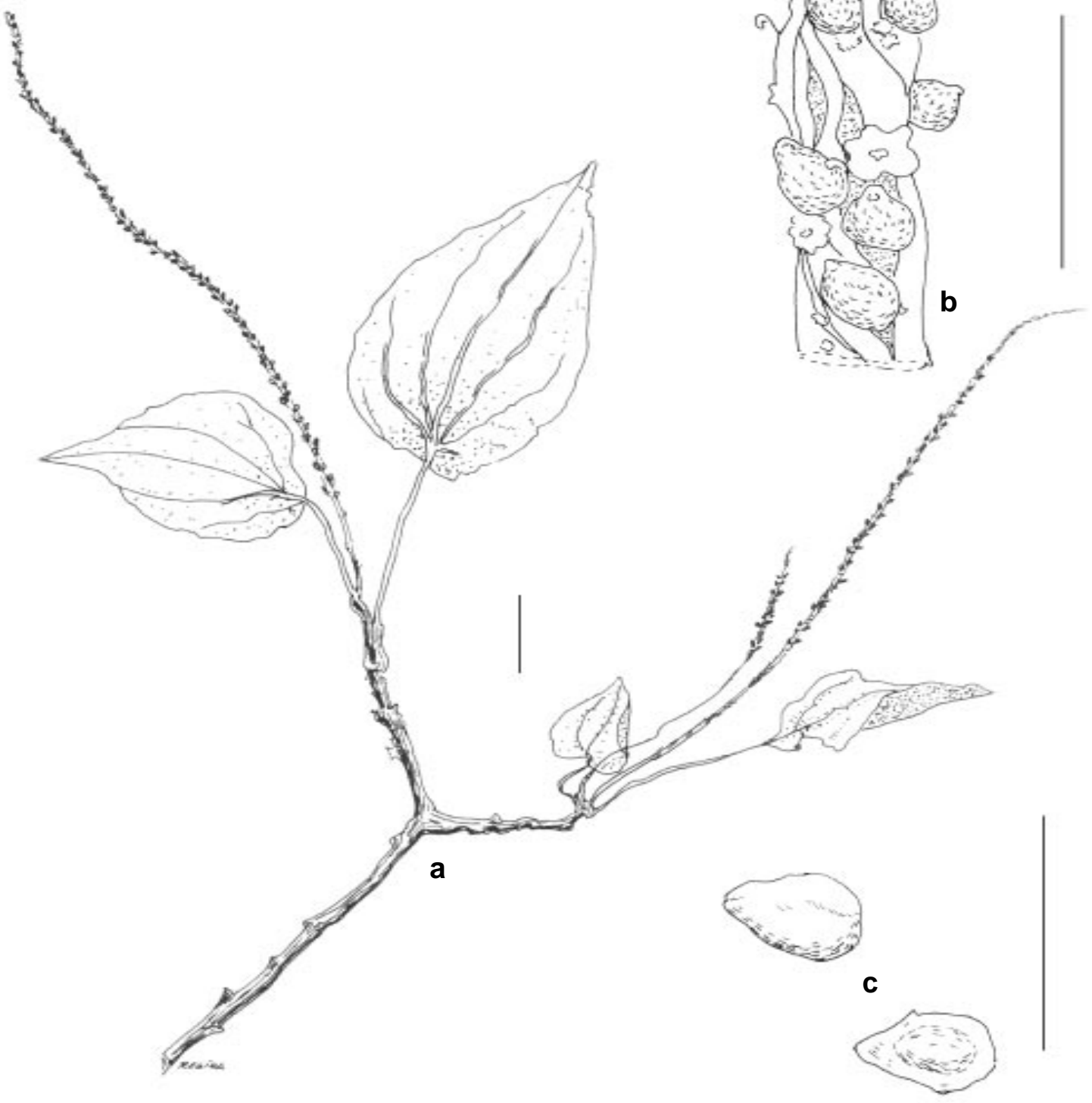

Figura 2 - Peperomia lanceolato-peltata C.DC.: a) hábito (escala $=1 \mathrm{~cm})$; b) parte da espiga mostrando bractéolas e frutos esparsos $($ escala $=1 \mathrm{~mm}) ; \mathrm{c})$ fruto $($ escala $=1 \mathrm{~mm})$.

Distribuição geográfica: Suriname e Brasil, nos estados do Amazonas, Amapá, Pará, Ceará, Rio de Janeiro, São Paulo, Paraná e Santa Catarina. Comentários: Presta-se para cultivo como ornamental.

Material examinado: Maranguape, topo da Serra, 28.VI.1981, E. Nunes \& P. Martins s.n. (RB 306718, EAC 10570); Serra de Baturité, IX-1910, E. Ule 9021 (NY).
2.6. Peperomia rotundifolia (L.) Humb., Bonpl. \& Kunth, Nov. gen. sp. 1: 65. 1815.

Piper rotundifolium L., Sp. pl. 30, 1753.

Erva delicada, epífita; caule delicado, crespo-puberulento a glabrescente. Folhas alternas; pecíolo glabrescente com ca.5 mm compr.; lâmina arredondada, 0,3-1,2 x 0,3-1,2 $\mathrm{cm}$, arredondada na base e no ápice, subpeltada e obscuramente contínua sobre o pecíolo; 
palmati-3-nervada, membranácea, crespopubescente. Espigas terminais, ca. $2 \mathrm{~cm}$ compr.; pedúnculo 4-5 mm compr.; raque glabra; bractéolas arredondado-peltadas; flores esparsas. Drupa globoso-ovóide, oblíquas no ápice.

Distribuição geográfica: Continente Americano e Antilhas. No Brasil, nos estados do Amazonas, Pará, Pernambuco, Minas Gerais, Rio de Janeiro, São Paulo, Santa Catarina e Rio Grande do Sul.

Comentários: Espécie geralmente com representantes epífitos nos troncos e ramos das árvores, não raro cultivados em vasos ou placas como ornamentais.

Material examinado: Serra de Baturité, Sítio B. Inácio, 1937, Pe. J. Eugênio Leite 466 p.p. (RB); Serra de Maranguape, 23.I.1968, Z. Trinta 1281, E. From Trinta 2214, E. Santos 2322 \& J. Sacco 2418 (R).

2.7. Peperomia tetraphylla (G.Forst.) Hook. \& Arn. var. tetraphylla, Bot. Beechey Voy.: 97, 1841. (Fig.1b)

Piper tetraphyllum G.Forst., Fl. ins. austr. 5. 1786.

Erva epífita; caule sulcado, com tricomas curtos ou longos, eretos ou curvos. Folhas 4verticiladas, curto-pecioladas; lâmina elíptica, 0,6-2 x 0,5-1,2 cm, carnosa, base e ápice agudos, glanduloso-pontuada na face adaxial, pubescente na abaxial. Espigas axilares ou terminais, eretas ou curvas; pendúculo 1-2,5 cm compr.; raque com tricomas pubescentes; bractéolas arredondadas, glandulosas; flores densamente agrupadas. Drupa elíptica, ca.2 $\mathrm{mm}$ diâm., com parte inferior imersa na raque. Distribuição geográfica: No Brasil, nos estados do Ceará, Pernambuco, Minas Gerais, Espírito Santo, Rio de Janeiro, São Paulo e Rio Grande do Sul.

Comentários: Espécie própria de lugar úmido e sombrio, geralmente crescendo em troncos ou ramos das árvores; pode ser cultivada como ornamental.

Material examinado: Serra de Barurité, IX.1910, Ule 9018 (B).
2.8. Peperomia circinata Link var. circinata, Jahrb. 1(3): 64. 1820.

Erva carnosa, delicada, reptante; caule crespo-pubescente. Folhas opostas, subsésseis; lâmina orbicular, 3-5 mm de diâm., obscuro-3nervada, crespo- pubescente em ambas as faces. Espigas pequenas, terminais, 1-2 cm compr.; pedúnculo ca. $2 \mathrm{~cm}$ compr., bi-bracteado, crespopubescente; raque glabra; bractéolas peltadoarredondadas; flores congestas. Drupa ovadoglobosa, aguda no ápice, submersa na raque.

Distribuição geográfica: Antilhas e América do Sul. No Brasil, nos estados do Amazonas, Pará, Mato Grosso, Goiás, Maranhão, Ceará, Minas Gerais, Rio de Janeiro, São Paulo, Paraná, Santa Catarina e Rio Grande do Sul. Comentários: Os espécimes ocorrem nos troncos das árvores e arbustos desenvolvidos, às vezes em troncos caídos nas matas, em locais sombrios; são cultivados como ornamental.

Material examinado: Aratuba, Sítio Jacarandá, 30.VIII.1980, M.A. Figueiredo s.n. (EAC 8923); Serra de Baturité, Sítio B. Inácio de Azevedo, 1937, Pe. J. Eugenio 466 p.p. (RB).

2.9. Peperomia blanda (Jacq.) Kunth, Nov. gen. sp. 1: 67. 1815.

Piper blandum Jacq., Collectanea 3: 211. 1789.

Erva rupestre, tomentosa. Folhas opostas ou verticiladas 3 a 3; pecíolo viloso; lâmina elíptica ou obovada, 1,5-3,5 x 1-2,7 cm, base aguda, ápice agudo ou obtuso, densamente vilosa quando jovem, quando adulta com tricomas vilosos em ambas as faces, mais profusos na face abaxial ao longo das nervuras. Espigas terminais, 6-14 cm compr.; pendúnculo 1,7-2 cm compr.; raque glabra; bractéolas arredondadas, glandulosas; flores esparsamente dispostas. Drupa globosoovóide, ápice oblíquo.

Distribuição geográfica: Antilhas e América do Sul. No Brasil nos estados de Roraima, Goiás (Brasília-DF), Ceará, Minas Gerais, Rio de Janeiro, São Paulo e Rio Grande do Sul. Material examinado: Serra de Baturité, 23.I.1915, Dusen 16470 (NY); id., Bico Alto, 23.IV.1909, Ducke s.n. (MG 2054). 
2.10. Peperomia decipiens C.DC., Notizbl. Bot. Gart. Berlin-Dahlem 6 (62): 493. 1917.

Erva ereta, com tricomas crespopubescentes variando até $0,1 \mathrm{~cm}$ compr. Folhas inferiores opostas e superiores comumente ternadas; pecíolo glabrescente; lâmina lanceolada ou lanceolado-elíptica, 5-8 x 1,3-2,5 cm, base cuneada, ápice agudo, 5-nervada, glabra em ambas as faces, se pilosa apresentando tricomas crespo-pubescentes apenas na nervura principal, ou, raramente, ao longo das nervuras secundárias, ciliada na margem. Espigas terminais e axilares, ca. $10 \mathrm{~cm}$ compr.; pedúnculo ca. $2-5 \mathrm{~cm}$ compr., crespo-pubescente; raque glabra; bractéolas arredondado-peltadas; flores esparsamente dispostas. Drupa globoso-ovóide, com ápice oblíquo, pseudocúpula ausente.

Distribuição geográfica: Brasil, nos estados de Roraima e Ceará.

Comentários: As folhas opostas e cuneadas determinam nesta espécie características para cultivo como ornamental; entretanto, trata-se de planta rara, endêmica do Brasil, coletada para documentação científica somente no início do século passado.

Material examinado: Serra de Baturité, Bico Alto, 12.VIII.1908, Ducke s.n. (MG 1535).

\subsection{Peperomia dahlstedtii C.DC., Candollea} 1: 305, 385. 1923.

Erva reptante, crassa, glabra. Folhas 2-3(4) em cada nó; pecíolo hirtelo; lâmina elíptica, elíptico-obovada, 2-3 x 1-2 cm, base subcuneada, ápice obtuso ou arredondado, levemente ciliado, 3-nervada, nervuras impressas na face adaxial e promínulas na face abaxial. Espigas terminais, ca.7 cm compr.; pedúnculo hirtelo, 1,5-2,5 cm compr.; raque glabra; bractéolas arredondadas; flores congestas. Drupa de ovóide a subcilíndrica, ápice agudo, pseudocúpula basal.

Distribuição geográfica: Brasil, nos estados do Amazonas, Ceará, Paraná e Mato Grosso. Comentários: Está assinalada pela primeira vez para o estado do Ceará.

Material examinado: Pacatuba, Serra da Aratanha, Sítio Pitaguarí, 09.X.1978, A. Fernandes s.n. (EAC 4188).

\section{Piper L., Gen. pl. 1: 333. 1737.}

Arbustos, subarbustos ou arvoretas, geralmente variando entre $1-10 \mathrm{~m}$ de altura, mais ou menos lignificados, ramosos, não raro nodosos. Folhas alternas, forma e tamanho variáveis. Espigas opostas às folhas, pedunculadas; raque sulcada, lisa, papilosa ou fimbriada; bractéolas variando em forma e tamanho, às vezes côncavas, concheiformes, não raro cuculadas, glabras, pilosas ou fimbriadas. Flores aperiantadas, densamente congestas ou laxas. Estames 2-5. Ovário de forma variável, glabro ou apresentando tricomas; estigmas 3, raro 2-4, sésseis ou não, persistentes no fruto. Drupas de forma variável, com pericarpo pouco espessado.

Espécie tipo: Piper nigrum L.

Distribuição geográfica: Gênero com larga distribuição pelas regiões tropicais e temperadas dos dois hemisférios. No Brasil, ocorrem cerca de 266 espécies, estando representado no Ceará por 13 espécies e 4 variedades.

\section{CHAVE PARA A IDENTIFICAÇÃO DAS ESPÉCIES E VARIEDADES DE PIPER}

1. Nervuras foliares partindo da base, palmatinérveas.

2. Lâmina foliar cordada na base, ciliada na margem

3. Lâmina foliar glabra em ambas as faces 3.1.1. P. marginatum var. marginatum 3'. Lâmina foliar com tricomas.

4. Tricomas nas nervuras em ambas as faces ...... 3.1.2. P. marginatum var. anisatum 4'. Tricomas adpressos na face adaxial e pubescentes nas nervuras da face abaxial 3.1.3. P. marginatum var. catalpifolium

2'. Lâmina foliar aguda ou atenuada na base, não ciliada na margem . 3.2. P. amalago var. medium 1'. Nervuras foliares não partindo da base, peninérveas.

5. Lâmina foliar assimétrica na base; bainha percorrendo toda a extensão do pecíolo, geralmente alada. 
6. Lâmina com base cordado-auriculada 3.3. P. cernuum var. cernuum

6'. Lâmina com base não cordado-auriculada.

7. Lâmina foliar de $8-15 \mathrm{~cm}$ compr.

8. Plantas arbustivas 3.4.1 P. tuberculatum var tuberculatum

8'. Plantas escandentes 3.4.2. P. tuberculatum var. scandens

7'. Lâmina foliar acima de $15 \mathrm{~cm}$ compr.

9. Lâmina até $9,5 \mathrm{~cm}$ larg., glabra em ambas as faces ......... 3.5.1. P. arboreum var. arboreum

9'. Lâmina além de $12 \mathrm{~cm}$ larg., glabra na face adaxial ou, ás vezes, pubescente ao longo das nervuras de ambas as faces 3.5.2. P. arboreum var. latifolium

5'. Lâmina foliar simétrica ou pouco assimétrica na base; bainha curta não percorrendo toda a extensão do pecíolo, geralmente formando uma cavidade na base ou em forma de canal, não alada ou, às vezes, levemente alada.

10. Nervuras secundárias dispostas, em relação à principal, até o ápice da lâmina.

11. Lâmina foliar com nervuras impressas na face adaxial; raque pubescente, bractéola cuculada; drupa tetragonal 3.6. P. bartlingianum

11'. Lâmina foliar com nervuras salientes na face adaxial; raque glabra, bractéola peltadoorbicular, marginalmente franjada; drupa oblonga ou obpiramidal 3.7.P. divaricatum

10'. Nervuras secundárias dispostas, em relação à principal, até a porção mediana, abaixo ou pouco acima.

12. Lâmina foliar com base simétrica 3.8. P. rufipilum

12'. Lâmina foliar com base assimétrica.

13. Lâmina glabra na face adaxial; estigmas em estilete longo ... 3.9. P. crassinervium 13'. Lâmina escabrosa na face adaxial; estigmas sésseis ou em estilete curto.

14. Tricomas na face abaxial da lâmina foliar, profusos, velutíneos, sedosos ao tato 3.10. P. mollicomum

14'. Tricomas na face abaxial das folhas, híspidos, ásperos ao tato.

15. Inflorescências com pedúnculo de $1-2 \mathrm{~cm}$ compr.

16. Lâmina foliar rômbica 3.11. P. dilatatum

16'. Lâmina foliar ovado-lanceolada 3.12. P. aduncum 15'. Inflorescências com pedúnculo até $1 \mathrm{~cm}$ compr.

17. Tricomas dos ramos escabrosos

3.13.1. P. hispidum var. hispidum

17'. Tricomas dos ramos adpressos

3.13.2. P. hispidum var. trachydermum

3.1.1. Piper marginatum Jacq. var. marginatum Icon. pl. rar. 2: 2. 1786-1793.

(Fig. 3)

Arbusto ou arvoreta com até $5 \mathrm{~m}$ de altura. Folhas com pecíolo de 2-6 cm compr.; lâmina ovada, $10-20$ x 7-15 cm, base cordada, ápice agudo ou acuminado, membranácea, glabra em ambas as faces, exceto pela presença da densa ciliação na margem; nervuras 7-11, palmatinérveas, às vezes, algumas coalescentes com a nervura principal. Espigas curvas até $15 \mathrm{~cm}$ compr.; pedúnculo
$1 \mathrm{~cm}$ compr.; bractéolas triangular-peltadas, franjadas. Estames 4-5. Drupa obpiramidal, glabra, 3 estigmas sésseis.

Distribuição geográfica: América Central, Antilhas e América do Sul. No Brasil, nos estados do Amazonas, Pará, Ceará, Paraíba e Pernambuco.

Comentários: No Ceará é conhecida como capeba-mansa e tem seus frutos usados como substitutos da pimenta-do-reino, à semelhança dos selvagens que a utilizam como condimento (Braga, 1953). Na Amazônia é conhecida 
como caa-peba-cheirosa, nhandi, nhandú, pimenta-do-mato, pimenta-dos-índios e pimenta-betel, sendo usada sob a forma de chá, considerada antiespasmódica para afecções do fígado e do baço; segundo os índios Tenharins são consideradas plantas tóxicas quando ingeridas e são por eles conhecidas por nhanbuí; as raízes, quando amassadas, são utilizadas para aliviar coceiras das picados de insetos (Di Stasi et al., 1989; Van Den Berg, 1993).

Peckolt \& Peckolt (1888), informam que a raiz é usada contra as mordeduras das cobras, aplicando-a no ferimento e, ao mesmo tempo, deve ser ingerida internamente sob forma de tintura. Esta parte do vegetal é empregada como mastigatório contra dores de dentes; é ainda carminativa.

Tillequin et al. (1978), isolaram das folhas 2 flavonóides: vitexin e marginatoside.
Material examinado: Pacoté, Serra de Baturité, Serrinha, 04.VI.1983, A. Fernandes \& Matos s.n. (EAC 12049); Maranguape, Serra de Maranguape, 26.VI.1981, P. Martins \& E. Nunes s.n. (EAC 10493; RB 311069).

\subsubsection{Piper marginatum var. anisatum} (Kunth) C.DC., Symb. antill. 3: 172, 1902.

Piper anisatum Kunth, Nov. gen. sp. 1: $58,1815$.

Esta variedade, com representantes conhecidos como capeba, é distinta das demais, por apresentar tricomas puberulentos nas nervuras de ambas as faces da lâmina foliar.

Distribuição geográfica: América Central, Antilhas e América do Sul. No Brasil, nos estados do Amazonas, Amapá, Pará, Ceará e Pernambuco.

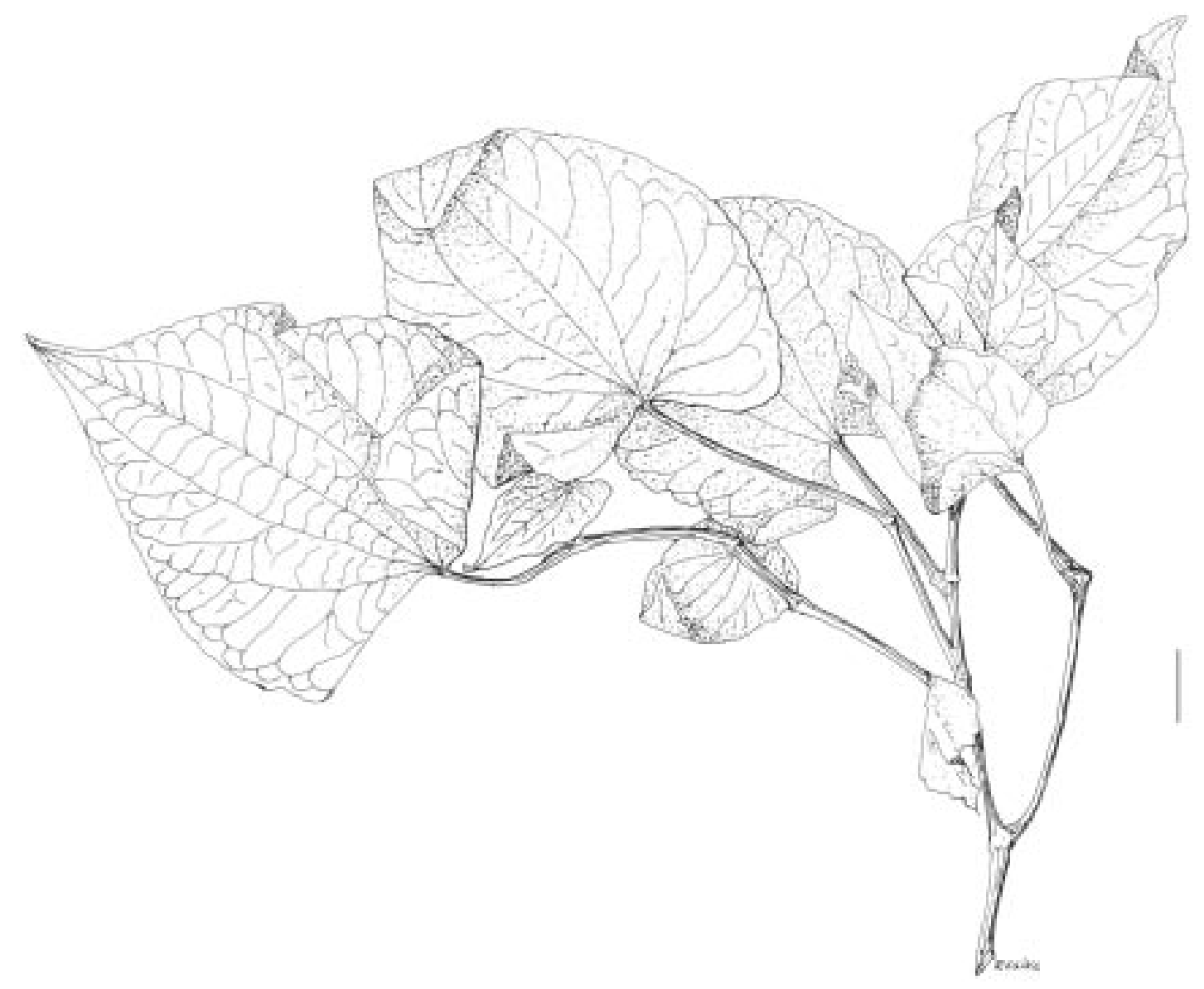

Figura 3 - Piper marginatum Jacq. var. marginatum : hábito $($ escala $=2 \mathrm{~cm}$ ). 
Material examinado: Serra de Maranguape, I.1992, M.C. do Nascimento s.n. (RB 296134).

\subsubsection{Piper marginatum var. catalpifolium} (Kunth) C.DC., Prodr. 16 (1): 246, 1869.

Piper catalpaefolium Kunth, Nov. gen. sp. 1: 58, 1815.

Esta variedade distingue-se da típica, por apresentar tricomas adpressos na face adaxial da lâmina foliar e pubescentes nas nervuras da face abaxial.

Distribuição geográfica: América Central, Antilhas e América do Sul. No Brasil, nos estados do Amazonas, Pará, Ceará, Paraíba, Pernambuco, Minas Gerais e Rio de Janeiro.

Comentários: Conhecida popularmente como capeba na América tropical, capeba-cheirosa na Amazônia e no Rio de Janeiro, nhandi e pimenta-do-mato no Amazonas e Pará, malvavisco em Pernambuco.

Material examinado: Aratanha, XI.1859, $\mathrm{Fr}$. Allemão 1467 (R); id., s.d., Bellard 24 (K); Pacote, Serra de Baturité, Serrinha, 04.VI.1983, A. Fernandes \& Matos s.n. (RB 311052).

\subsection{Piper amalago var. medium (Jacq.)} Yunck., Brittonia 14: 189, 1962.

(Fig. 4 a-b)

Piper medium Jacq., Icon. pl. rar. 1: 2, 1786.

Arbusto com 3-7 m de altura, glabro, tanto semi-umbrófilo como heliófilo, muito freqüentes nas formações secundárias. Folhas com pecíolo até $1 \mathrm{~cm}$ compr.; lâmina oblongo-lanceolada, largo-elíptica ou ovada, 5-13 x 3,5-9,5 cm, base aguda ou atenuada, ápice acuminado, membranácea, agradavelmente odorífera quando triturada, glabra na face adaxial, pubescente nas nervuras e vênulas na face abaxial; nervuras até 7 pares que partem da base da lâmina, palmatinérveas, sendo que, geralmente, as 3 mais centrais convergem no ápice, as 2 laterais seguem paralelamente até aproximadamente a metade da lâmina, anastomosando-se por laços até a porção superior. Espigas ereto-patentes, 6-7 cm compr.; pedúnculo 0,8-1,5 cm compr.; bractéolas obovado-côncavas com o dorso papiloso.
Estames 5-6. Drupa com ápice agudo, glabra, 34 estigmas arredondados, sésseis.

Distribuição geográfica: América Central, Antilhas e América do Sul. No Brasil, nos estados do Ceará, Pernambuco, Bahia, Minas Gerais, Rio de Janeiro, São Paulo, Paraná, Santa Catarina, Rio Grande do Sul e Mato Grosso.

Comentários: Espécie comum na América tropical, freqüente nas margens de rios e formações secundárias à beira de estradas.

Considerada medicinal, tendo principalmente as folhas e os frutos como partes utilizadas; as folhas sob a forma de cataplasmas, ou pelo cozimento, são empregadas em banhos ou chás, devido suas propriedades sudoríferas acentuadas são úteis ainda para os males do estômago; os frutos são estimulantes tanto quanto àqueles de Piper nigrum L. (pimenta-do-reino); é planta muito própria no tratamento das cardialgias, uma enfermidade comum nas Antilhas, aí conhecida como "soot-soot", e em Cuba como "mataguao" (Roig y Mesa, 1945).

Peckolt \& Peckolt (1888), informam que a medicina popular usa uma tintura preparada com as espigas frescas e álcool fraco na proporção 1 para 2 partes, respectivamente, para aplicação no tratamento de reumatismos. Acrescentam que as raízes maceradas com aguardente, na dose de um cálice de 10 em 10 minutos, atuam contra as mordeduras de cobras, aplicando ao mesmo tempo a raiz fresca com vinagre sobre a ferida produzida por esses animais.

Material examinado: Serra de Baturité, Bico Alto, 23.IV.1909, Ducke s.n. (MG 2022); s.1., s.d., “ex-Herb. J. de Saldanha 8095” (R).

3.3. Piper cernuum Vell. var. cernuum, Fl. flumin. 26. 1825 .

(Fig. 4 c-e)

Arbusto com 2-3,5 m de altura, ciófilos; ramos e pecíolos ferrugíneo-tomentosos. Folhas com bainha alada percorrendo toda a extensão do pecíolo, 6-10cm compr.; lâmina ovado-elíptica, $20-40 \mathrm{~cm}$ compr., $14-15 \mathrm{~cm}$ 

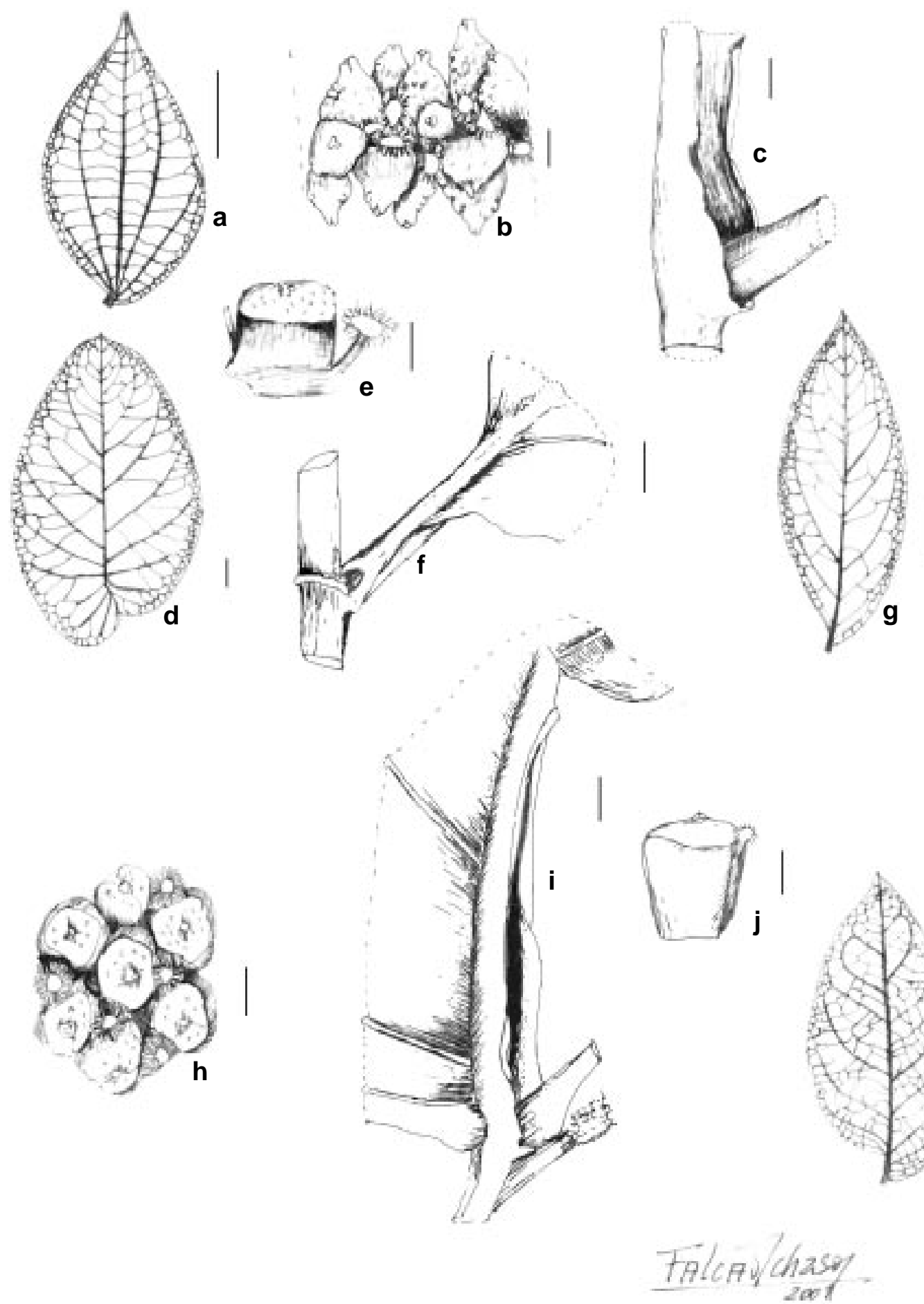

Figura 4 - Piper amalago var. medium (Jacq.) Yunck: a) detalhe da folha (escala $=5 \mathrm{~cm}$ ); b) parte da espiga, detalhando bractéolas e frutos (escala $=1 \mathrm{~mm})$. Piper cernum Vell. var. cernum: $\mathrm{c}$ ) parte da bainha foliar (escala $=3 \mathrm{~mm})$; detalhe da folha (escala $=3 \mathrm{~mm}$ ); e) bractéola e fruto (escala = $1 \mathrm{~mm}$ ). Piper divaricatum Meyer: $\mathrm{f}$ ) detalhe da bainha foliar (escala $=1 \mathrm{~mm}) ; \mathrm{g})$ detalhe da folha $($ escala $=1 \mathrm{~cm}) ; \mathrm{h})$ parte da espiga, detalhando bractéolas e frutos (escala $=1 \mathrm{~mm})$. Piper arboreum var. arboreum: i) detalhe da bainha foliar (escala $=3 \mathrm{~mm}) ; \mathrm{j}$ ) bractéola e fruto $($ escala $=1 \mathrm{~mm}) ; 1)$ detalhe da folha (escala $=1 \mathrm{~mm})$. 
larg., base assimétrica, cordado-auriculada, com lobos arredondados diferindo um lado em relação ao outro em ca. $10 \mathrm{~mm}$ compr., ápice agudo ou obtuso, papiráceo-membranácea, glabra na face adaxial, ferrugíneo-tomentosa na face abaxial; nervuras secundárias ascendentes, peninérveas, as da aurícula maior dirigidas para baixo. Espigas recurvadas ultrapassando as folhas em quase metade ou do mesmo comprimento; pedúnculo $3-5 \mathrm{~cm}$; bractéolas peltadas, margem com tricomas ferrugíneo-hirtos. Estames 4. Drupa lateralmente comprimida, com tricomas no ápice depresso, 3 estigmas sésseis.

Distribuição geográfica: Brasil, nos estados de Amazonas, Ceará, Bahia, Minas Gerais, Espírito Santo, Rio de Janeiro, São Paulo, Paraná e Santa Catarina.

Comentários: Conhecida como bojubú, paude-cobra-cipó, jaborandi-cepoti e pimenta-demorcego, é uma espécie com representantes de belo porte, folhas magníficas e longas inflorescências pêndulas, que se prestam para ornamentação de locais com solo rico, úmido e sombrio.

Peckolt \& Peckolt (1888), informam que o suco das espigas em aguardente é de uso interno contra mordedura de cobra e que o bagaço misturado com raízes deve ser aplicado sobre o ferimento produzido pelo animal. Segundo estes autores a raiz é considerada um medicamento sialagogo e diurético; o pó resultante das espigas secas é útil para tratamento de gonorréias crônicas e leucorréias.

Material examinado: Guaramiranga, Riacho do Capim, 24.VII.1908, Ducke 1394 (MG); Maranguape, topo da Serra, 28.VI.1981, P. Martins \& E. Nunes s.n. (EAC 10552; RB 306721); Serra do Baturité, 600m alt., IX.1897, Schwacke 270 (MG).

3.4.1. Piper tuberculatum Jacq. var. tuberculatum, Collectanea 2: 2. 1788.

(Fig. 5 a-d)

Arbusto com ca. 2-2,5 cm de altura; ramos pubérulos. Folhas com bainha alada; pecíolo 0,5-1cm compr., pubérulo; lâmina oblongo-elíptica ou ovado-elíptica, 8-12,5 x 4$6 \mathrm{~cm}$, base assimétrica, ápice agudo, papiráceomembranácea, brilhante, glabra na face adaxial, pubérula nas nervuras na face abaxial; nervuras ascendentes em número de 8-10 pares, peninérveas, dispostas até o ápice da lâmina. Espigas eretas, com 4-7cm compr.; pedúnculo 1-1,5cm compr.; bractéolas triangular-subpeltadas, marginalmente franjadas. Estames 4. Drupa tetragonal, ovada ou subobovada, lateralmente comprimida, glabra, 3 estigmas sésseis.

Distribuição geográfica: Continente Americano e Antilhas. No Brasil, nos estados do Amazonas, Pará, Maranhão, Piauí, Ceará, Paraíba, Pernambuco, Rio de Janeiro e Mato Grosso.

Comentários: No Ceará é conhecida como pimenta-de-macaco ou pimenta-longa, considerada planta medicinal como estimulante e carminativa (Braga, 1953). Cresce em altitudes aproximadas aos $550 \mathrm{~m}$, em encosta úmida, em capoeira e em locais brejosos.

Material examinado: Fortaleza, 1948, Dias da Rocha s.n. (RB 148570); id., 20.VII.1964, R. Bataleiro \& A. Castellanos 25191 (GUA, RB); id., Sítio Fundão, 10.VIII.1993, M.A. Figueiredo \& M. Mata s.n. (EAC 20043; RB 311054); Capistrano, Serra do Vicente, 16.X.1979, E. Nunes \& A.J. Castro s.n. (EAC 7092; RB 311056); Fortaleza, Campos do Pici, 14.II.1985, E. Nunes s.n. (EAC 12985; RB 311057); Ipu, Bica do Ipu, 19.XII.1979, E. Nunes \& P. Martins s.n. (EAC 7870; RB 311053); id., s.d., M.A. Figueiredo s.n. (EAC 23616; RB 331744); Jardim, Centro, IX.1988, E. Maciel s.n. (RB 290959); Maranguape, Santo Antonio do Baraco, 10.X.1935, F. Dronet 2597 (F, GH, MO, SP); id., Serra de Maranguape, X.1910, Ule 9014 (L, NY, US); Pacatuba, 1859, Fr. Allemão 1465 \& Cysneiros (R); id., s.d., Fr. Allemão 1466 \& Cysneiros (R); Pacoté, Serra de Baturité, Sítio Germinal, 31.VII.1971, P. Bezerra s.n. (EAC 373); id., residência do Sr. Augusto Alves, 25.IX.1981, F.S. Cavalcante \& F. Bruno s.n. (EAC 10863); Redenção, Sitio Canadá, 


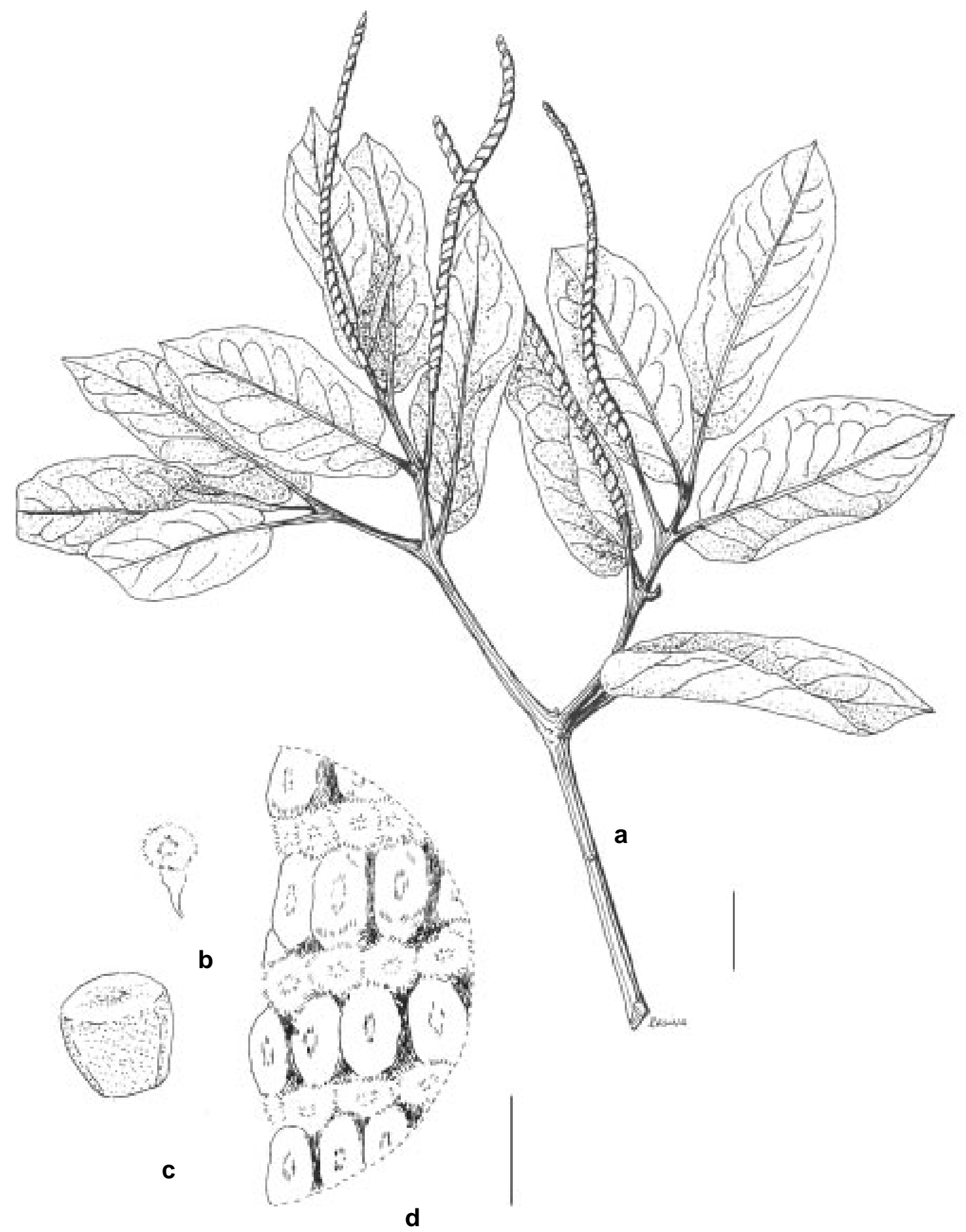

Figura 5 - Piper tuberculatum Jacq. var. tuberculatum. a) hábito (escala $=2 \mathrm{~cm}$ ); b) bractéola (escala $=1 \mathrm{~mm})$; c) fruto $($ escala $=1 \mathrm{~mm}) ; \mathrm{d})$ parte da espiga, detalhando bractéolas e frutos $($ escala $=1 \mathrm{~mm})$. 
9.X.1980, P. Martins \& E. Nunes s.n. (EAC 8968; RB 311058); id., 9.X.1980, P. Martins \& E. Nunes s.n. (EAC 8970; RB 306725); Serra de Baturité, Sítio B. Inácio de Azevedo, 16.X.1939, Leite 461 (RB); Ubajara, Serra da Ibiapaba, PN Ubajara, 05.VII.1978, A. Fernandes \& Matos s.n. (EAC 3977); id., PN Ubajara, 24.IX.1981, A. Fernandes \& Matos s.n. (EAC 10787; RB 311055); id., Riacho Cafundó, 02.XI.1978, A. Fernandes et al. s.n. (EAC 5075); Viçosa, Traguço, 21.VI.1972, D. Sucre 9266 \& J.F. da Silva (RB); s.l., 8.IX.1984, G. Pinto 307(RB); s.l., V.1917, Dias da Rocha 18 (RB); s.l., s.d., Rocha 61 (ILL); s.l., s.d., Saldanha 8096 (R); s.l., s.d., Gardner 1846 (BM, K, NY, US, W); s.l., s.d., Loefgreen 610 (R); s.l., s.d., Curran 42 (GH, NY, US).

3.4.2.Piper tuberculatum var. scandens Trel. \& Yunck., Piper. North. South Amer.: 367. 1950.

Distinta da variedade típica pelo caule escandente e pela lâmina foliar com 9-15 x 5$7 \mathrm{~cm}$.

Distribuição geográfica: América do Sul. No Brasil, encontrada somente no Ceará.

Comentário: Conhecida igualmente como a variedade típica por "pimenta-de-macaco".

Material examinado: Maranguape, Hotel Pirapora, 15.VIII.1935, F. Dronet 2273 (R, NY, US).

3.5.1. Piper arboreum Aubl. var. arboreum, Hist. pl. Guiane 1: 23. 1775.

(Fig. 4 i-l)

Arbusto com 2-4m de altura. Folhas com bainha alada; pecíolo 0,5-2 cm compr.; lâmina lanceolado-elíptica, $15-27$ x 4,5-9,5 cm, base obliquamente assimétrica, ápice acuminado, papirácea ou membranáea, glabra em ambas as faces; nervuras secundárias 8-13, peninérveas, alternas, ascendentes, dispostas até o ápice da nervura principal. Espigas eretas, 7-12 cm compr., apiculadas no ápice; pedúnculo $0,5-2 \mathrm{~cm}$; bractéolas triangularpeltadas, fimbriadas na margem. Estames 4. Drupa subquadrangular, comprimida lateralmente, glabra, 3 estigmas sésseis.
Distribuição geográfica: Antilhas e América do Sul. No Brasil, ocorre nos estados do Amazonas, Ceará, Pernambuco, Bahia, Rio de Janeiro, São Paulo, Paraná, Santa Catarina, Rio Grande do Sul e Mato Grosso.

Comentários: Conhecida como alecrim-deangola ou pau-de-angola, é popularmente utilizada na Amazônia sob a forma de chá e banhos aromáticos contra reumatismos, bronquites, resfriados e gripes fortes, sendo ainda carminativa e emoliente; sua raiz nesta região é conhecida como raiz-de-pahim (Van Den Berg, 1993).

Peckolt \& Peckolt (1888), informam que no estado do Rio de Janeiro é conhecida como jaborandi-do-rio, jaborandi-falso, pimenta-domato, fruta-de-morcego e joão-brandi, cujas folhas tem óleo de sabor picante, com aroma semelhante ao do hortelã-pimenta, sendo empregadas como sudoríficas e afrodisíacas; as raízes, folhas, inflorescências e ramos jovens são as partes utilizadas nas dores de garganta e dentes; os pequenos frutos são apreciados pelos morcegos.

Material examinado: Guaramiranga, Sítio Guaramiranga, 16.VI.1989, M.A. Figueiredo et al. s.n. (EAC 16726); Serra de Baturité, IX.1910, Ule 9012 (K); id., Sítio Caridade, 21.IX.1939, Pe. José Eugênio 470 (RB); Tianguá, Chapada da Ibiapaba, 02.XI.1986, A. Fernandes et al. s.n. (EAC 14849; RB 311067); Crato, Parque Nacional do Araripe, 19.I.1983, T.C. Plowman 12744 (EAC).

3.5.2. Piper arboreum var. latifolium (C.DC.) Yunck., Bol. Inst. Bot. São Paulo 3: 82, 1966.

Piper geniculatum var. latifolium C.DC., Prodr. 16 (1): 267. 1869.

Difere da variedade típica por apresentar ramos de crespo-pubescentes a tomentosos, lâmina foliar mais larga, além de $12 \mathrm{~cm}$, glabra na face adaxial e pubescente ao longo das nervuras da face abaxial ou, ás vezes, pubescente ao longo dos nervos de ambas as faces (Yuncker, 1973). 
Distribuição geográfica: América do Sul. No Brasil, ocorrente nos estados do Amazonas, Ceará, Bahia, Minas Gerais, Rio de Janeiro, Paraná e Santa Catarina.

Comentários: Não há material botânico procedente do Ceará nos herbários brasileiros consultados; Yuncker (1973) cita o exemplar coletado por Ule 9013 na Serra de Baturité, depositado no Herbário G e por Rocha 104, sem localidade especificada, depositado no ILL.

\subsection{Piper bartlingianum (Miq.) C.DC., Prodr.} 16 (1): 257. 1869.

Artanthe bartlingiana Miq., Syst. piperac. 510. 1844.

Arbusto com ca. $4 \mathrm{~m}$ de altura. Folhas curto-pecioladas; pecíolo canaliculado apresentando bainha basal; lâmina elípticooblonga, $17-22$ × 6-8 cm, base simétrica, aguda, ápice agudo, cartácea; nervuras 6-7 pares, peninérveas, dispostas até o ápice da lâmina, impressas na face adaxial, salientes na abaxial. Espigas eretas, $10-14 \mathrm{~cm}$ compr., $0,5 \mathrm{~cm}$ de diâm.; pedúnculo 0,3-0,5 cm compr.; raque pubescente; bractéolas cuculadas, com pedicelo pubescente. Estames 4. Drupa ovadotetragonal, glabra, com 4 estigmas sésseis.

Distribuição geográfica: Brasil, nos estados do Amazonas, Amapá, Pará, Ceará.

Comentários: Espécie citada por Yuncker (1973) para o estado do Ceará, através do exemplar coletado por Ducke s.n. em Triguesia Velha, em 14.XII.1912, depositado no Herbário MG, não tendo sido encontrado nenhum outro material nos demais herbários consultados; para exemplificar esta espécie foi utilizado material de outro estado.

Material adicional examinado: Estado do Pará, Santarém, estrada para a cachoeira do Palhão, igarapé do Guaraná, 4.XII.1966, $P$. Cavalcante 1567 \& M.Silva (RB).

3.7. Piper divaricatum G.Mey., Prim. fl. esseq. 15, fig. 86. 1818.

(Fig. 4 f-h)

Arbusto com até $7 \mathrm{~m}$ de altura, dotado de glândulas, glabro. Folhas com bainha curta, pecíolo sulcado com 1-3,5 cm compr.; lâmina oblongo-elíptica ou lanceolada, 8-14 x 3-7 cm, base assimétrica e decurrente, ápice agudo, revoluta na margem, papirácea, brilhante em ambas as faces; nervuras secundárias 5-7, salientes na face adaxial, dispostas até o ápice da lâmina. Espigas eretas ou pêndulas, até 6 $\mathrm{cm}$ compr., $5 \mathrm{~mm}$ diâm., alcançando na frutificação até $1 \mathrm{~cm}$ diâm.; pedúnculo 1-1,5 $\mathrm{cm}$; raque glabra; bractéolas peltadoorbiculares, marginalmente franjadas. Estames 4. Drupa oblonga ou obpiramidal, glandulosa no ápice, 3 estigmas sésseis.

Distribuição geográfica: América do Sul. No Brasil, nos estados do Amazonas, Amapá, Pará, Ceará, Pernambuco, Bahia, Minas Gerais, Espírito Santo, Rio de Janeiro e Mato Grosso.

Comentários: Espécie das matas alagadiças dos estados do Ceará, Bahia, Pernambuco, Espírito Santo, Rio de Janeiro e Minas Gerais, com folhas brilhantes e pontos translúcidos. Peckolt \& Peckolt (1888), informam que a raiz é aromática, de sabor forte, semelhante ao do gengibre; as folhas e as raízes, quando em infusão, são empregadas internamente contra dores reumáticas e cólicas, e, quando cozidas, são utilizadas sob a forma de banhos antireumáticos; é conhecida com os nomes populares de "betys", "bettle" e "betre".

Material examinado: Aratuba, Sítio Brejo, 17.X.1979, A. Fernandes s.n. (EAC 4168); Pacatuba, Serra da Aratanha, Sítio Pitaguari, 3.X.1979, Martins \& Castro s.n. (EAC 7049; RB 306728); Serra de Baturité, IX.1910, E. Ule 9016 (NY); id., perto do Sítio Santa Clara, 9.XII.1937, Pe. José Eugênio 463 (RB); s.l., s.d., A. Fernandes s.n. (EAC 20431).

3.8. Piper rufipilum Yunck., Bol. Inst. Bot. São Paulo 3: 121. 1966.

Arbusto com caule liso, glabrescente, avermelhado. Folhas com pecíolo vermelho, até 2,5 cm compr.; lâmina elíptica ou oblongoelíptica, 17-19 x 8-11 cm, base simétrica, arredondada ou curto-aguda, ápice subagudo, finamente membranácea, glabra na face adaxial, tricomas crespo-pubescentes e 
vermelhos nas nervuras da face abaxial, translúcida pela presença de aréolas; nervuras 3-5, ascendentes, dispostas até a porção mediana. Espigas eretas, $8 \mathrm{~cm}$ compr.; pedúnculo ca. $2 \mathrm{~cm}$ compr., glabro; raque glabra; bractéolas triangular-subpeltadas. Estames 4. Drupa comprimida, retangulartruncada, glabra, 2 estigmas sésseis.

Distribuição geográfica: Ocorrendo somente no Brasil, sendo endêmica no estado do Ceará. Material examinado: Crato, s.d., Fr. Allemão 1464 (R - Holótipo).

3.9. Piper crassinervium Kunth, Nov. gen. sp. 1: 48, 1815.

Arbusto com 2-5 m de altura, glabro ou pubescente. Folhas longo-pecioladas com bainha até a metade ou acima do pecíolo; lâmina oblongolanceolada ou ovada, $12-15 \times 5-9 \mathrm{~cm}$, base assimétrica ou subsimétrica, ápice acuminado, papirácea ou cartácea, glabra ou pubescente, na face adaxial, glandulosa; nervuras secundárias 4-6, ascendentes, dispostas ao longo da nervura principal até ou abaixo do meio da lâmina. Espigas eretas, com 5-8 cm compr.; pedúnculo ca. $2 \mathrm{~cm}$ compr., glabro; bractéolas triangular-subpeltadas, franjadas na margem. Estames 4. Drupa arredondado-ovóide, glabra, 3 estigmas em estilete longo.

Distribuição geográfica: América do Sul. No Brasil nos estados do Amazonas, Ceará, Minas Gerais, Rio de Janeiro, São Paulo, Paraná e Santa Catarina.

Material examinado: Guaramiranga, Riacho do Capim, 24.VII.1908, Ducke s.n. (MG 1390).

3.10. Piper mollicomum Kunth, Linnaea 13: 648, 1839.

Arbusto com 1-1,5 m de altura, tomentoso-viloso. Folhas com bainha curta; pecíolo 0,8-1 cm compr.; lâmina ovado-elíptica ou lanceolado-elíptica, $10-12$ x 4,5-8 cm, base assimétrica, cordada, ápice acuminado, papirácea, dotadas de glândulas translúcidas, tricomas escabrosos na face adaxial, profusos, velutíneos e sedosos ao tato na abaxial; nervuras secundárias 5-6, ascendentes, dispostas ao longo da lâmina, até ou abaixo da porção mediana. Espigas curvas, 9,5-15 cm compr.; pedúnculo 0,5-1,5 cm compr., hirsuto; bractéolas triangular-peltadas, profusamente franjadas. Estames 4. Drupa obovóide, reticulada, glabra, às vezes glandular, 3 estigmas sésseis, recurvos.

Distribuição geográfica: Brasil, nos estados do Ceará, Paraíba, Pernambuco, Minas Gerais, Espírito Santo, Rio de Janeiro, São Paulo, Santa Catarina, Mato Grosso e Goiás.

Comentários: Espécie conhecida como jaborandi-manso ou simplesmente jaborandi; possui frutos úteis para problemas estomacais, sendo também muito usados em doenças venéreas; suas raízes são utilizadas como mastigatórios, para anestesiar as dores de dentes (Peckolt \& Peckolt, 1888).

Seus exemplares são bastante freqüentes em matas úmidas, nas restingas ou em altitudes que variam entre 200-600 m s.m., à beira das estradas, em locais ensolarados ou semisombrios.

Material examinado: Guaramiranga, Riacho do Capim, 6.VIII.1908, Ducke s.n. (MG 1510); id., Serra de Baturité, 13.I.1994, A. Fernandes s.n. (EAC 20430; RB 311066); Serra de Aratanha, mata úmida, 10.XI.1983, A. Fernandes s.n. (EAC 12228; RB 306724); Serra de Baturité, IX.1910, Ule 9017 (NY, US).

3.11 Piper dilatatum Rich., Actes Soc. Hist. Nat. Paris: 105, 1792.

Arbusto com 1-2 m de altura, de pubescente a glabrescente; ramos estriados. Folhas com bainha abaixo da porção mediana do pecíolo, esse com 0,5-1 cm compr.; lâmina rômbica ou elíptica, às vezes obovada ou ovada, 11-21 x 7,5-10,5 cm larg., base assimétrica, cordada, obtusa ou aguda, ápice acuminado ou falcado, membranácea, escabrosa, crespo-pubescente a glabrescente na face adaxial; nervuras secundárias 5-6, ascendentes, geralmente puberulentas, dispostas até a porção mediana da principal. Espigas retas ou curvas, obtusas ou apiculadas, 6,5-12 cm compr.; pedúnculo, 1-2 cm compr., 
de glabro a pubescente; bractéolas arredondadopeltadas, fimbriadas na margem. Estames 4. Drupa obpiramidal-trigonal, papiloso-puberulenta no ápice, 3 estigmas sésseis.

Distribuição geográfica: Antilhas e América do Sul. No Brasil, nos estados do Amazonas, Amapá, Pará, Maranhão, Pernambuco, Bahia, Minas Gerais, São Paulo, Paraná, Santa Catarina e Mato Grosso.

Material examinado: Serra do Vicente, Capistrano, 13.V.1980, P. Martins \& E. Nunes s.n. (EAC 8568; RB 311074); Maranguape, próximo a Pirapora, 26.VI.1981, P. Martins \& E. Nunes s.n. (EAC 10484; RB 311078); Pacatuba, Serra da Aratanha, Sítio Pitaguari, 1.X.1979, P. Martins \& A.J. Castro s.n. (EAC 6985; RB 306727); Pacoti, entre Pacoti e Palmácia, 12.II.1981, A. Fernandes \& Matos s.n. (EAC 9667; RB 306717); id., Serrinha, 4.VI.1983, A. Fernandes \& P. Bezerra s.n. (EAC 12062; RB 306726); id., Serra de Baturité, 01.III.1992, M.A. Figueiredo et al. s.n. (EAC 18471; RB 311104); Serra de Baturité, Sítio B. Inácio de Azevedo, 21.XI.1939, Pe. José Eugênio, S.J. 472 (RB); Baturité, Serra de Baturité, s.d., C.F.M. Delphin s.n. (RB 311100); Ipu, Bica do Ipu, 19.XII.1979, P. Martins \& E. Nunes s.n. (EAC 7871; RB 311146); s.1., s.d., “ex-Herb. J. Saldanha 8094” (R).

3.12. Piper aduncum L., Sp. pl.: 29, 1753. Arbusto ou arvoreta até $8 \mathrm{~m}$ de altura, muito nodoso. Folhas com pecíolo de $0,3-0,8$ cm compr., lâmina elíptica, ovado-elíptica ou ovado-lanceolada, 10-15(-23) x 4-7 cm, base assimétrica, arredondado-cordada, ápice agudo ou acuminado, escabrosa, áspera ao tato em ambas as faces, glandulosa; nervuras secundárias 6-8, dispostas até ou pouco acima da porção mediana. Espigas curvas, 7-14 cm compr., 0,2-0,3 cm diâm.; pedúnculo $1-2 \mathrm{~cm}$ compr., pubescente; bractéolas triangularsubpeltadas, margem franjada. Estames 4. Drupa obovóide, tri- ou tetragonal, glabra, 3 estigmas sésseis.

Distribuição geográfica: América Central, Antilhas e América do Sul. No Brasil nos estados do Amazonas, Amapá, Pará, Mato Grosso, Ceará, Bahia, Minas Gerais, Espírito Santo, Rio de Janeiro, São Paulo e Paraná.

Comentários: No nordeste brasileiro é conhecida como pimenta-de-fruto-ganchoso, tapa-buraco e aperta-ruão; por esse último nome também é conhecida no sudeste, pricipalmente em São Paulo, por suas propriedades medicinais (Pereira, 1929). No estado do Amazonas os indivíduos desta espécie são denominados popularmente como pimenta-de-macaco ou pimenta-longa, e suas folhas são utilizadas sob a forma de chá contra apatia intestinal e males estomacais (Van Den Berg, 1993).

Espécie vulgarmente conhecida em Cuba como "platanillo-de-Cuba"; "canilha de ruerto" e "comdocillo" no México; "higuillo" e "higuillo oloroso" em Porto Rico; "cordoncillo blanco" na Venezuela; "oijú-yú” em Trinidad. Neste país, existe medicamento patenteado com o nome de Cannagina, cujas partes usadas são as folhas, frutos e raiz (Roig y Mesa, 1945; 1988).

Os espécimes são adstringentes e diuréticos, sendo um hemostático poderoso local em feridas, úlceras e leucorréias (Uphof, 1959). Suas espigas curvas e aromáticas contém taninos, essências e resinas; a infusão das folhas é usada como estomáquica, balsâmica, adstrigente e desobstruente do fígado (Lainetti \& Brito, 1980).

Material examinado: Serra de Araripe, s.d., Gardner s.n. (NY).

3.13.1. Piper hispidum Sw. var. hispidum, Prodr. 15. 1788.

Arbusto com 2-4 m de altura, com tricomas escabrosos nos ramos. Folhas com pecíolo de 0,5-1cm compr., híspido, bainha basal; lâmina elíptica ou ovado-elíptica, 10-16 x 5-8 cm, base assimétrica, um dos lados arredondados e diferindo do outro em ca.3-5 $\mathrm{cm}$ compr., quando simétrica aguda, ápice acuminado, cartáceas, escabrosas ou híspidas na face adaxial e hirsutas na abaxial, profundamente glandulosas; nervuras secundárias 4-5, ascendentes, dispostas abaixo 
ou pouco acima da porção mediana da lâmina. Espigas eretas, 8-14 cm compr.; pedúnculo até $1 \mathrm{~cm}$ compr., hirtelo; bractéolas triangularpeltadas e franjadas na margem. Estames 4. Drupas oblongas ou lateralmente comprimidas, papiloso-puberulentas no ápice, com 3 estigmas persistentes sésseis.

Distribuição geográfica: América Central, Antilhas e América do Sul. No Brasil, nos estados do Amazonas, Pará, Ceará, Pernambuco, Bahia, Rio de Janeiro, Paraná, Santa Catarina e Mato Grosso.

Comentários: Conhecida como matico, apertajoão, matico-falso. As folhas, as raízes e os frutos são adstrigentes, diuréticos e estimulantes, empregados como desobstruentes do fígado. Em Cuba é conhecida como "platanillo-de-cuba", utilizada para deter hemorragias traumáticas (Roig y Mesa, 1945).

Peckolt \& Peckolt (1888), informam que as folhas são utilizadas sob a forma de banhos contra as hemorróidas, reumatismos e desinterias; quando frescas são usadas como emplastros em hernia de umbigo de crianças; tendo o mesmo uso no estado seco e reduzido a pó, sendo ainda consideradas hemostáticas. Os frutos são anti-blenorrágicos.

Material examinado: Serra de Baturité, IX.1910, Ule 9015 (L).

\subsubsection{Piper hispidum var. trachydermum} (Trel.) Yunck., Ann. Missouri Bot. Gard. 37: 33, 1950.

Piper trachydermum Trel., Contr. U.S. Natl. Herb. 26: 33. 1927.
Esta variedade distingue-se da típica pela presença de tricomas nos ramos curtos, vigorosos, acima curvados e mais ou menos adpressos, segundo análise de material de outros estados brasileiros (Yuncker, 1972).

Distribuição geográfica: Panamá e Brasil, nos estados do Amazonas, Amapá, Pará, Ceará, Alagoas, Bahia, Espírito Santo, Rio de Janeiro, São Paulo e Paraná.

Comentários: Variedade citada em literatura para o estado do Ceará, sob coleta de Fr. Allemão 1464 (ILL) e de Gardner 1848 (P), exemplares não examinados.

4. Pothomorphe Miq., Bull. Sci. Phys. Nat. Neerl.: 450, 1839.

Arbustos ou ervas bem desenvolvidas. Folhas longo-pecioladas, grandes e largas, peltadas ou não; nervuras em números de 12 pares ou mais, a principal com duas ramificações laterais acima da base; as secundárias anastomosando-se por meio de laços; nervuras transversais abundantes; nas imediações do bordo, anastomose de nervuras de ordem inferior. Flores dispostas em espigas densas, longas e delicadas, formando uma umbela no fim de um pedúnculo axilar. Estames 2. Ovário trigonal, glabro, com 3 estigmas sésseis, recurvos, persistentes nos frutos. Drupas obpiramidais ou obpiramidal-angulosas, 5-6 mm compr., glabras.

Espécie tipo: Pothomorphe peltata (L.) Miq.

\section{CHAVE PARA A IDENTIFICAÇÃO DAS ESPÉCIES DE POTHOMORPHE}

1. Folhas peltadas 4.1. P. peltata

1'. Folhas não peltadas 4.2. P. umbellata

4.1. Pothomorphe peltata (L.) Miq., Comm. phytogr. 37. 1840.

Piper peltatum L., Sp. pl. 1: 30. 1753.

Arbusto alcançando $2 \mathrm{~m}$ de altura. Folhas peltadas, pecíolo 9-20 cm compr., glabro, bainha alada; lâmina ovado-cordada ou arredondado-cordada, $12-25 \times 12-25 \mathrm{~cm}$, base aguda, ápice acuminado, provida de pontos translúcidos, palmatiforme; nervuras 13-15 pares. Espigas 5-10 cm compr., cada uma apresentando pedúnculo com 1-1,5 cm compr., dispostas em pedúnculo comum, 4-7 cm 
compr., glabro; bractéolas peltadas, fimbriadas na margem. Drupa obpiramidal-trigonal.

Distribuição geográfica: América Central, Antilhas e América do Sul. No Brasil, ocorre nos estados do Amazonas, Pará, Maranhão, Ceará e Mato Grosso.

Comentários: Conhecida na Amazônia como caapeba-do-norte, capeba-verdadeira, capebabranca; as folhas frescas são úteis para as dores hepáticas; quando cozidas e moídas são emolientes e empregadas como cataplasmas sobre tumores; importante ainda no tratamento do herpes e erupções cutâneas; quando maceradas com azeite são aplicadas sobre ventre inflamado (Braga, 1953; Van Den Berg, 1993).

Em Cuba é conhecida como "caisimon", em Porto Rico como "basquina" e no México como "mano de zopilote"; é empregada como emoliente na inflamação dos testículos e para tumores; a raíz é estimulante e diurética, útil para as obstruções do fígado (Roig y Mesa, 1988).

Material examinado: Ceará, s.l., s.d., Gardner s.n. (U).

4.2. Pothomorphe umbellata (L.) Miq., Comm. phytogr. 36. 1840.

Piper umbellatum L., Sp. pl. 1: 30. 1953.

Arbusto com 1-3 m de altura. Folhas não peltadas, pecíolo 20-25 cm compr., puberulento, bainha alada; lâmina arredondado-ovada ou reniforme, 14-24 x 17-25 cm, base cordada, ápice agudo ou abruptamente acuminado, provida em toda face adaxial de tricomas híspidos com 2,5-3 mm compr., relativamente esparsos, dotada de glândulas translúcidas, palmatiformes; nervuras 12-16 pares. Espigas com 6-9 cm compr., cada uma apresentando pedúnculo com 5-7 mm compr., dispostas em pedúnculo comum, 1-1,5 cm compr., pubescente; bractéolas triangular-subpeltadas, glandulosas, fimbriadas na margem. Drupa obpiramidal-angulosa.

Distribuição geográfica: América Central, Antilhas e América do Sul. No Brasil, ocorre nos estados do Amazonas, Pará, Ceará, Bahia, Rio de Janeiro, São Paulo e Mato Grosso.
Comentários: Conhecida popularmente no Ceará como capeba; em outros estados, como caa-peuá, catajé, lençol-de-santa-bárbara, malvarisco e pariparoba; suas folhas e raízes são empregadas sob a forma de chá nas doenças do fígado, baço e rim, como contra inchaços e inflamções das pernas (Braga, 1953; Guimarães et al., 1978; Di Stasi et al., 1989).

$\mathrm{Na}$ Amazônia, toda a planta, principalmente as folhas, são utilizadas sob a forma de chá, suco ou emplastro, como antiblenorrágica, vermífuga e no combate das inflamações internas e externas em machucados ou queimaduras (Van Den Berg, 1993).

Peckolt \& Peckolt (1888), informam que o suco das folhas frescas, misturado com um pouco de vinagre é empregado nas hemoptises, e, se acrescido de sal de cozinha, é utilizado pelos camponeses nas contusões e sob a forma de xaropes para tosses e bronquites.

Freise (1934), assinala que esta espécie contém óleo essencial de cheiro acanforado, gosto picante, tendo a asarona como componente principal, e como princípio ativo a chavina, pariparobina e piperina.

Zurlo \& Brandão (1989), mencionam, dentre outras ervas comestíveis, a capeba, fornecendo outros nomes populares, cultivo, uso medicinal popular, incluindo receitas para uso culinário.

Vieira (1992), informa sua utilização como diurético sob a forma de chá em dosagens de $10 \mathrm{~g}$ para 1 litro de água ingerindo-se três xícaras ao dia.

Em Cuba é reconhecida pelo nome popular "caisimon"; é considerada apropriada para o trato digestivo, além de suas folhas, quando cozidas, serem utilizadas como cicatrizantes para feridas (Roig y Mesa, 1988). Material examinado: Aratuba, Sítio Brejo, 18.X.1978, A. Fernandes s.n. (EAC 4171); Maranguape, Serra de Maranguape, estrada Pirapora a Castelo, 27.VI.1981, E. Nunes \& P. Martins s.n. (EAC 10537); Pacatuba, Serra da Aratanha, 01.X.1979, P. Martins \& A.J. Castro s.n. (EAC 6988); Serra de Baturité, 
caminho para Guaramanga, 23.VI.1939, Pe. José Eugênio, S.J. 462 (RB); id., Sítio São João, 1939, Pe. José Eugênio, S.J. 467 (RB).

\section{CONCLUSÕES}

Tem-se o conhecimento que a flora do Brasil detém uma das maiores biodiversidades do planeta. Assim, é imperativo que se procedam a estudos taxonômicos nas espécies silvestres, não raro esquecidas, visando-se, com isso, o desenvolvimento de pesquisas nos países sul-americanos que não dispõem de matéria-prima suficiente para o abastecimento da indústria farmacêutica.

Este trabalho, ao tratar do conhecimento taxonômico das Piperaceae do estado do Ceará, teve como objetivo identificar as plantas, tendo em vista que há informações de algumas como medicinais.

Por outro lado, este estudo pretendeu contribuir para a seleção daquelas de valor econômico, ameaçadas e conservadas ou, ainda, para definir endemismo, entre outros aspectos, daquela região.

As coleções dos Herbários nacionais e estrangeiros propiciaram as condições básicas para o desenvolvimento deste trabalho, tendo sido analisadas as dos séculos passados, particularmente as de Pe. José Eugênio, Fr. Allemão, Saldanha, Ule, Ducke, Dusen, Curran, Bellard, Gardner e Loefgren, e as mais recentes, assinaladas para E. Nunes, P. Martin, Fernandes, Nascimento, Bezerra, D. Sucre, Figueiredo, Castellanos, Maciel.

No estado do Ceará, onde as coletas de Piperaceae são deficientes, observa-se que algumas espécies estão em herbários representadas apenas pelo exemplar tipo, como é o caso de Piper rufipilum Yunck.; outras são bastante comuns no território nacional, mas constam nas coletas para o Ceará de 1 a 3 exemplares. Há necessidade, portanto, de coletas intensivas de espécimes da família nesse Estado.

Assinala-se neste trabalho o endemismo de Piper rufipilum Yunck., espécie encontrada nas florestas úmidas da chapada de Araripe, considerada rara, dado que, sua única coleta foi realizada no século XIX, por volta de 18591861. Peperomia lanceolato-peltata C.DC., com representantes em outros países da América do Sul, no Brasil tem ocorrência apenas no Estado do Ceará, segundo material herborizado examinado. A espécie Piper guianensis (Klotzsch) C.DC. não foi incluída neste trabalho, muito embora, Yuncker (1972) a tenha citado para o Ceará, com base em material coletado por Gardner s.n. depositado nos herbários de G e SP; a consulta a estes herbários revelou a ausência desta exsicata, o que impossibilitou uma análise para fins de confirmação da ocorrência do táxon.

\section{AGRADECIMENTOS}

Aos curadores dos herbários, pelo empréstimo dos materiais.

Ao Conselho Nacional de Desenvolvimento Científico e Tecnológico CNPq, pela bolsa concedida.

\section{REFERÊNCIAS BIBLIOGRÁFICAS}

Agardh, C. A. 1824. Aphorismi botanici. Lund (Berling), vol. 14, p.199-214.

Aublet, J. B. C. F. 1775. Histoire des plantes de la Guiane Françoise. Londres, Paris (Pierre-Françoise Didot Jeune), v. 1, p. $1-621$.

Braga, R. 1953. Plantas do Nordeste, especialmente do Ceará. Centro de Divulgação Universitária - Estudos e Ensaios Biblioteca de Divulgação e Cultura Publicação no 2, ser. 1a ., 523 p.

Brummitt, R. K. \& Powell, C. E. 1992. Authors of plant names. Kew, Royal Botanic Gardens, 732 p.

Candolle, A. C. P. de. 1866. Piperaceae novae. J. Bot. 4: 132-147.

Candolle, A. C. P. de. 1869. Piperaceae. In: Candolle, A. L. P. P. de (ed.) Prodromus Systematis naturalis regni vegetabilis. Paris (Treuttel et Wurtz), Strasbourg, London, vol. 16, part. 1, p. 235-471. 
44

1902. Piperaceae. Symbolae

Antillanae 3: 159-274.

1917. Piperaceae. In: Pilger, R. K. F. (ed.) Plantae uleanae novae vel minus cognitae. Notzb. Bot. Gart. BerlinDahlem 6: 485-497.

1923. Piperaceae clavis analytica. Candollea 1: 66-415.

Dietrich, A. G. 1831. Piperaceae. In: Linnaeus, C. (ed.), Species Plantarum. Editio Sexta. Berlin (G.C. Nauck), v. 1, 735p.

Di Stasi, L. C.; Santos, E. M. G.; Santos, C. M. dos \& Hiruma, C. A. 1989. Plantas medicinais na Amazônia. São Paulo: Editora Universidade Estadual Paulista, $194 \mathrm{p}$.

Forster, J. G. A. 1786. Florulae insularum australium prodromus. Goettingen (Joann. Cristian Dieterich).

Fosberg, F. R. \& Sachet, M. H. 1975. Flora of Micronesia 2: Casuarinaceae, Piperaceae and Myricaceae. Smithsonian Contribution to Botany 24: 27 p.

Freise, F. W. 1934. Piper umbellatum L. In: Freise,F. W. Plantas medicinais brasileiras. Boletim de Agricultura. Diretoria de Publicidade Agrícola Secretaria de Agricultura, Indústria e Comércio do Estado de São Paulo, no único, p. 179.

Guimarães, E. F. 1984. Notas em Piperaceae II. Considerações sobre o gênero Ottonia Sprengel no Brasil. Bol. Mus. Bot. Kuhlmann 7(3): 61-84.

. 1988. Flora Fanerogâmica da Reserva do Parque Estadual das Fontes do Ipiranga, São Paulo, Brasil. Piperaceae. Hoehnea 15: 46-51.

; Ichaso, C. L. \& Costa, C. G. 1978.

Piperáceas. 1. Ottonia, 2. Sarcorhachis, 3. Pothomorphe. In: Reitz, P. R. (ed.), Flora Ilustrada Catarinense, fasc. Pipe.: $1-26$.

; Ichaso, C. L. \& Costa, C. G. 1984.

Peperomia. In: Reitz, P. R. (ed.) Flora
Guimarães, E. F. \& Giordano, L. C.S.

Ilustrada Catarinense, fasc. Piperáceas: 1-136.

Holmgren, P. J.; Holmgren, N. H. \& Barnett, L. C. 1990. Index Herbariorum. Part 1: the herbaria of the world. Regnum vegetabile. New York Botanical Garden, Bronx, New York, ed. 8, 693p.

Hooker, W. J. \& Arnott, G. A. W. 1830-1841. The Botany of Captain Beechey's Voyage. London (Henry G. Bohn), p. 1485, pl. 1-99.

Ichaso, C. L. F.; Guimarães, E. F. \& Costa, C. G. 1977. Piperaceae do Município do Rio de Janeiro - I. O gênero Piper L. Arq. Jard. Bot. Rio de Janeiro 20: 145-188.

Jacquin, N. J. 1786-1793. Piper. In: Jacquin, N. J., Icones plantarum rariorum. Vindobonae [Wien], vol. 2, p. 1-22.

1788. Collectanea. Vindobonae [Wien] (ex officina Wappleriana) v. 2, 374p., pl. 1-18.

1789. Collectanea. Vindobonae [Wien] (ex officina Wappleriana) v. 3, 306p., pl. 1-23.

Kunth, K. S. 1815. Piperaceae. In: Humboldt, Bonpland \& Kunth (eds.), Nova genera et species plantarum. Lutetiae Parisiorum [Paris] (Sumptibus librariae graeco-latini-germanicae,...), vol. 1, p. 4661,14 tab.

1839. Bemerkungen über die familie der Piperaceen. Linnaea 13: 561-726.

. 1840. Observations sur la familie des Piperacées. Ann. Sci. Nat. 14: 173-220.

Lainetti, R. \& Brito, N. R. S. 1980. A saúde pelas plantas e ervas do mundo inteiro. Ed. Tecnoprint Ltda., 163 p.

Link, H. F. 1820. Piperaceae. Jahrb. 1(13): 60-65.

Linnaeus, C. 1737. Genera plantarum. Lugduni batavorum (Apud Coradum Wishoff), p. 1-372.

. 1753. Piper. In: Linnaeus, C. Species Plantarum. Holmiae [Stockholm] 
(Impensis Laurentii Salvii], vol. 1, p. 2830.

Meyer, G. F. W. 1818. Piperaceae. In: Meyer, G. F. W. Primitiae florae essequeboensis. Gottingae [Göttingen] (Sumptibus Henrici Dieterich), p. 15-16, fig. 86.

Miquel, F. A. W. 1839. Note preliminaire sur les genres de la familie Piperacées. Bull.

Sci. Phys. Nat. Neerl. 1: 446-453.

1840. Observationes de Piperaceis et Melastomataceis. Commentarii Phytographici. Lungduni batavorum [Leiden] (apud S. \& J. Luchtmans,...), vol. 2. p. 31-65, 6 tab.

1843. Systema piperacearum. Roterodami [Rotterdam] (apud H.A. Kramers), vol. 1, p. 1-304.

1844. Systema piperacearum. Roterodami [Rotterdam] (apud H. A. Kramers), vol. 2, p. 305-575.

Peckolt, T. \& Peckolt, G. 1888. História das plantas medicinaes e úteis do Brazil. Rio de Janeiro, Laemmert, 1369 p.

Pereira, H. 1929. Pequena contribuição para um Dicionário das plantas úteis do Estado de São Paulo. Tipografia Brasil de Rothschild \& Co., p. 78, 433.

Richard, L. C. M. 1792. Piper dilatatum. Actes Soc. Hist. Nat. Paris, 1 vol., p. 105.

Roíg y Mesa, J. T. 1988. Dicionario Botânico de nombre vulgares Cubanos. La Habana, Ed. Cientifico-tecnica, vol. 1 (AL), 599 p.; vol. 2 (Li-Z), 1142 p.

1945. Plantas medicinales, aromáticas o venenosas de Cuba. Habana, Ministerio de Agricultura, partes I/II, $872 \mathrm{p}$.

Ruiz, H. \& Pavon, J. 1794. Flora Peruvianae et Chilensis prodromus. Madrid (en la imprenta de Sancha), vol. 1, 154p.

Silva Teixeira, Z. da; Batista Almeida, M. S.; Castro Rassy, M. E. de \& Teixeira Alves,
E. 1991. Plantas medicinais mais conhecidas na comunidade previdenciária e a realidade quanto ao seu uso. Medicinas tradicionais e medicina ocidental na Amazônia (Contribuições científicas apresentadas no Encontro de Belém - 27/ novembro a 1\%dezembro de 1999), Belém, Pará, p. 399-400.

Sprengel, K. 1820. Neue Entdeckungen im ganzen Umfang der Pflanzenkunde. Leipzig (bey Friedrich Fleischer), vol. 1, $452 p$.

Swartz, O. 1788. Nova Genera et Species Plantarum seu Prodromus. M. D. Holmiae [Stockholm], Upsaliae [Upsala], \& Aboae [Abo] (in bibliopoliis acad. M. Awederi) 158p.

Tillequin, F.; Paris, M.; Jacquemin, H. \& Paris, R. R. 1978. Flavonóides de Piper marginatum. Planta médica - Journal of Medical Plant Research 33: 46-52.

Trelease, W. 1927. The Piperaceae of Panama. Contr. U.S. Natl. Herb. 26: $15-50$.

\& Yuncker, T. G. 1950. The Piperaceae of Northern South America. Univ. Illinois Press Publ. Vol. 2, 838 p., 674 fig.

Uphof, J. V. T. 1959. Dictionary of economic plants. Published by H.R. Engelmann (J. Cramer), $400 \mathrm{p}$.

Van Den Berg, M. E. 1993. Piperaceae. In: Van Den Berg, M. E. Plantas medicinais na Amazônia - contribuição ao seu conhecimento sistemático. Belém, PR/ MCT/CNPq, p. 55-66.

Velloso, J. M. C. 1829 (1825). Piperaceae. In: Velloso, J. M. C. Florae fluminensis. Flumine Januário [Rio de Janeiro] (ex Tipographia nationali), p. 24-27.

1831 (1827). Piperaceae. In: Velloso, J. M. C. Florae fluminensis Icones. Parisiis ex off. lithogr., Senefelder, v. 1, t. 54-65. 
Vieira, L. S. 1992. Fitoterapia da Amazônia: Manual de Plantas Medicinais (A Farmácia de Deus). 2a ed., São Paulo, Agronômica Ceres, 347 p.

Wikstrom, J. E. 1928. Öfversigt af ön Guadeloupe's Flora. Kongl. Vetensk. Acad. Handl., p. 56-57.

Yuncker, T. G. 1950. Piperaceae. In: Woodson \& Schery, Flora of Panama. Ann. Missouri Bot. Gard. 37: 1-120.

1962. Nomenclatural notes on Piperaceae. Brittonia 14: 188-190.

1966. New species of Piperaceae from Brazil. Bolm. Inst. Bot. São Paulo 3: $370 \mathrm{p}$.

1972. The Piperaceae of Brazil, I. Piper - Group I, II, III, IV. Hoehnea 2: 19-366.

1973. The Piperaceae of Brazil, II: Piper - Group V, Ottonia; Pothomorphe; Sarcorchachis. Hoehnea 3: 29-284.

. 1974. The Piperaceae of Brazil, III: Peperomia - taxa of uncertain status. Hoehnea 4: 71-413.

Zurlo, C. \& Brandão, M. 1989. As ervas comestíveis: descrição, ilustração e receitas. Editora Globo Rural, Coleção do Agricultor: Ecologia, 167 p. 